CALIBRATION OF A DISSOLVED-SOLIDS MODEL FOR THE YAMPA RIVER BASIN

BETWEEN STEAMBOAT SPRINGS AND MAYBELL, NORTHWESTERN COLORADO

By Randolph S. Parker and David W. Litke

U.S. GEOLOGICAL SURVEY

Water-Resources Investigations Report 86-4190

Prepared in cooperation with the

U.S. BUREAU OF LAND MANAGEMENT

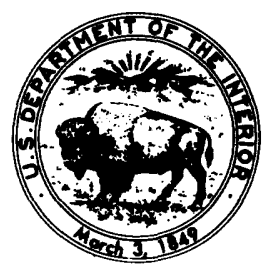

Lakewood, Colorado 
DEPARTMENT OF THE INTERIOR

DONALD PAUL HODEL, Secretary

U.S. GEOLOGICAL SURVEY

Dallas L. Peck, Director

For additional information write to:

District Chief

U.S. Geological Survey

Water Resources Division

Box 25046, Mail Stop 415

Denver Federal Center

Denver, CO 80225
Copies of this report can be purchased from:

U.S. Geological Survey Books and Open-File Reports Federal Center, Bldg. 41 Box 25425

Denver, CO 80225

[Telephone: (303) 236-7476] 
CONTENTS

Page
1
1
2
5
9
12
12
12
12
15
19

22
24
28
35
36
37

\section{FIGURES}

Figure 1. Map of study area-_. Page

2. Graph showing annual mean streamflow for Yampa River near Maybel1 (09251000), water years 1922-82 4

3. Diagram of a simple stream network with nodes and node numbers for the model 6

4. Diagram of the stream system showing node locations and numbers-..... 11

5-16. Graphs showing:

5. A comparison of calibrated model data and measured streamflow at node 27, Yampa River below diversion, near Hayden (09244410)-_. 26

6. A comparison of calibrated model data and measured dissolved-solids concentration at node 27, Yampa River below diversion, near Hayden (09244410)-...-.

7. A comparison of calibrated model data and measured total dissolved-solids load at node 27, Yampa River below diversion, near Hayden (09244410)

8. A comparison of calibrated model data and measured streamflow at node 39 , Yampa River at Craig (09247500)-10

9. A comparison of calibrated model data and measured dissolved-solids concentration at node 39, Yampa River at Craig (09247500)

10. A comparison of calibrated model data and measured total dissolved-solids load at node 39, Yampa River at Craig (09247500) 
Figures 5-16. Graphs showing--Continued:

11. A comparison of calibrated model data and measured streamflow at node 51, Williams Fork at mouth, near Hamilton (09249750)--.-.-.-

12. A comparison of calibrated model data and measured dissolved-solids concentration at node 51 , Williams Fork at mouth, near Hamilton (09249750)--.-.-.-.-.-

13. A comparison of calibrated model data and measured total dissolved-solids load at node 51, Williams Fork at mouth, near Hamilton (09249750)-------

14. A comparison of calibrated model data and measured streamflow at node 72 , Yampa River near Maybell (09251000)--...-

15. A comparison of calibrated model data and measured dissolved-solids concentration at node 72, Yampa River near Maybell (09251000)-..................... 34

16. A comparison of calibrated model data and measured total dissolved-solids load at node 72 , Yampa River near Maybell (09251000)

TABLES

Table 1. Water-resource information available at stations for use at input and output nodes in the model- 10

2. Linear-regression equations of the logarithm of instantaneous streamflow and dissolved-solids concentrations for input nodes -

3. Linear-regression equations of the logarithm of instantaneous streamflow and dissolved-solids concentrations for output

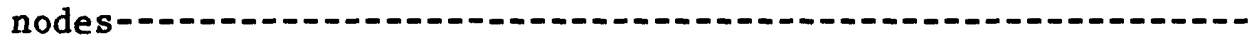

4. Error analysis for modeled monthly mean streamflow, dissolvedsolids concentration, and dissolved-solids load for 72 months at node 27, Yampa River below diversion, near Hayden (09244410)

5. Error analysis for modeled monthly mean streamflow, dissolvedsolids concentration, and dissolved-solids load for 72 months at node 39, Yampa River at Craig (09247500)

6. Error analysis for modeled monthly mean streamflow, dissolvedsolids concentration, and dissolved-solids load for 72 months at node 51, Williams Fork at mouth, near Hamilton (09249750) -

7. Error analysis for modeled monthly mean streamflow, dissolved-
solids concentration, and dissolved-solids load for

7. Error analysis for modeled monthly mean streamflow, dissolved-
solids concentration, and dissolved-solids load for

72 months at node 72, Yampa River near Maybell (09251000)--72 months at node 72 , Yampa River near Maybell

8. Linear-amflow, North Fork Elkhead Creek near Elkhead (09245500)

inear-regression equations for predicting monthly mean streamflow for node 37 , Fortification Creek near Craig (09246900) 
Table 10. Linear-regression equations for predicting monthly mean streamflow for node 40, East Fork Williams Fork, above Willow Creek (09248600) 40

11. Linear-regression equations for predicting monthly mean streamflow for node 44, South Fork of Williams Fork, near Pagoda (09249200)

\section{CONVERSION FACTORS}

The inch-pound units used in this report may be converted to metric (International System) units by using the following conversion factors:

Multiply inch-pound unit

cubic foot per second square mile ton (short)
By

0.02832

2.590

907.2
To obtain metric unit cubic meter per second square kilometer kilogram

Degree Celsius $\left({ }^{\circ} \mathrm{C}\right)$ may be converted to degree Fahrenheit $\left({ }^{\circ} \mathrm{F}\right)$ by using the following equation:

$$
{ }^{\circ} \mathrm{F}=9 / 5^{\circ} \mathrm{C}+32
$$




\title{
CALIBRATION OF A DISSOLVED-SOLIDS MODEL FOR THE YAMPA RIVER BASIN BETWEEN STEAMBOAT SPRINGS AND MAYBELL, NORTHWESTERN COLORADO
}

By Randolph S. Parker and David W. Litke

\begin{abstract}
A model for determining cumulative effects of streamflow, dissolvedsolids concentration, and dissolved-solids load was calibrated for the Yampa River and its tributaries in northwestern Colorado. The model uses accounting principles. It establishes nodes on the stream system and sums water quantity and quality from node to node in the downstream direction. The model operates on a monthly time step for water years 1976 through 1981. Output is monthly mean streamflow, dissolved-solids concentration, and dissolved-solids load. Streamflow and dissolved-solids data from streamflow-gaging stations and other data-collection sites were used to define input data sets to initiate and to calibrate the model. The model was calibrated at four nodes and produced results that generally were within 10 percent of the measured values. The calibrated model can be used to compute changes in streamflow and dissolved-solids concentration, and load resulting from the cumulative effects of new coal mines or the expansion of old coal mines in the Yampa River basin.
\end{abstract}

\section{INTRODUCTION}

Coal mining has increased in northwestern Colorado in response to the increased need for energy in the Nation. Because of the accessibility of coal and the availability of transportation, many coal mines have been established in the Yampa River basin. In addition, some mines are being expanded, and new sites have been proposed for mining.

As mining activity increases in any river basin, there is concern regarding the cumulative effects of mines on the water resources. A concentration of mining activity ultimately can produce combined effects larger than any predicted effects from a single mine. Computing these cumulative effects is difficult because the combined effects of several mines may be very complex.

The difficulty in determining the effects of mining is evident in the variability of the dissolved-solid concentrations and loads in streamflow draining these areas. Changes can cause the water to become unsuitable for many uses. In addition, a major concern is that any increase in dissolved solids in the Yampa River main stem may add to the problem of increasing dissolved-solids concentrations and loads in the Colorado River. A model to compute the dissolved-solids concentrations and loads in the Yampa River basin provides a method to examine the combined effects on water quality from several mines in the basin.

The purpose of this report is to describe a calibrated model for simulating streamflow and dissolved solids in the Yampa River and its tributaries. The model was calibrated in cooperation with the U.S. Bureau of Land 
Management as one method of combining proposed coal mining with water-resource information for evaluating proposed leasing of tracts for coal mining. This report wi11: (1) Describe the study area; (2) describe the model; (3) identify the available data; (4) describe the data used in the model; (5) describe model calibration results; and (6) identify data needs. This model uses available data from the basin and is calibrated to existing conditions.

Output from the calibrated model presented in this paper is assumed to represent 1976-81 water-year conditions. Alterations to the model easily can be made to represent particular hypothesized mine development during this same time period. The comparisons between these 1976-81 conditions and a particular mining situation provide the assessment of the cumulative effects during the 6 years. These 6 years are assumed to be representative of a typical sequence of years in terms of the hydrology in this basin. This period contains both wet and dry years and enables the user to examine a wide range of hydrologic conditions. An example of how this model is used in assessing cumulative hydrologic effects is given in Parker and Norris (1983).

\section{THE STUDY AREA}

The Yampa River basin (fig. 1) is hydrologically typical of many coal regions in Colorado. Much of the streamflow of the main stem of the Yampa River is derived from snow in the mountains. The geology of these mountains is different from the geology in the basin where the coal areas are located. The basic rock types in the mountains are igneous and metamorphic and result in streamflow that has small dissolved-solids concentrations. Coal mines are located in sedimentary-rock areas that may yield water with large dissolved-solids concentrations.

The streams within the active coal area can be classified into two groups--minor tributaries and major tributaries. Flow in the minor tributaries draining sedimentary-rock basins may contain naturally occurring large concentrations of dissolved solids. In general, most mining activity occurs in these small basins. The major tributaries receive water from several minor tributaries and carry the water to the Yampa River. Water use increases substantially in these major tributaries.

The study area includes a drainage area of 2,806 square miles between the streamflow-gaging stations--Yampa River at Steamboat Springs (09239500) and Yampa River near Maybel1 (09251000)--in Moffat and Routt Counties of northwestern Colorado (fig. 1). About 68 percent of the annual mean streamflow at the streamflow-gaging station--Yampa River near Maybell (09251000)--originates upstream from the confluence of the E1k and Yampa Rivers just downstream from Steamboat Springs. Downstream from this confluence, precipitation and topographic relief decrease considerably. The Williams Fork, Elkhead Creek, Milk Creek, Fortification Creek, and Trout Creek are the major tributaries that contribute most of the remaining flow. The majority of this additional water comes from Williams Fork and Elkhead Creek.

Most of the coal-mining activity is south of the Yampa River. To the north of the river, coalbeds dip farther underground, which increases the overburden and diminishes the potential for coal-mine operations. 


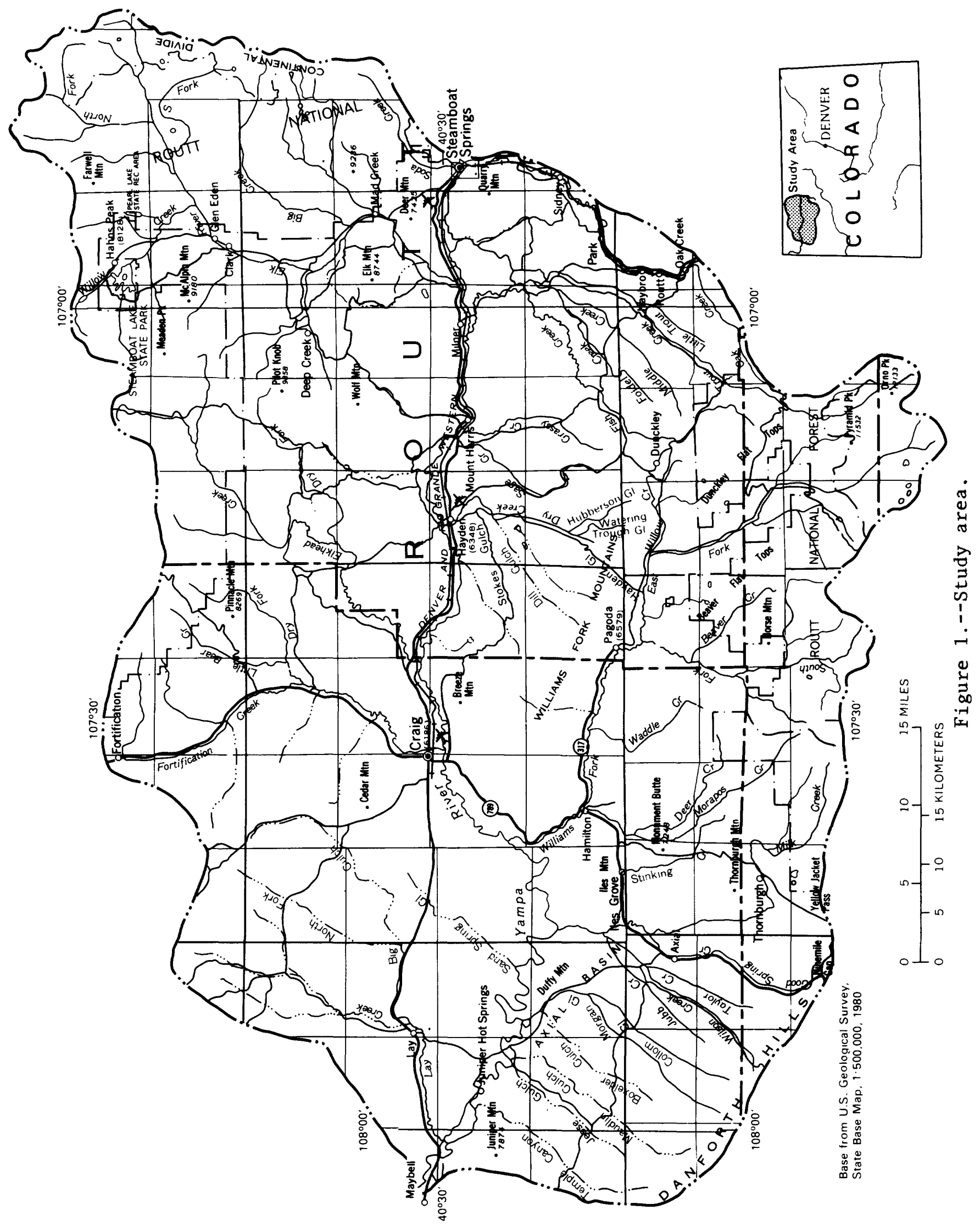


Collection of streamflow and associated water-quality data primarily was limited to the Yampa River prior to water year 1976. Data collection on the Yampa River was important because it is the primary surface-water resource of northwestern Colorado and is an important link in the Colorado River system. As interest grew in understanding water resources in the coal areas, additional streamflow-gaging stations and miscellaneous sites were established. The U.S. Bureau of Land Management funded a large part of this data-collection activity from 1976 through 1981 (Maura, 1982). This period (water years 1976 through 1981) has the most complete record of hydrologic data for the coa1mining areas; therefore, the data for the model in this report are based on this 6-year period.

Streamflow for the period of record for Yampa River near Maybell (09251000) is shown in figure 2. As shown, streamflow during the 6-year study fluctuated considerably and is representative of the variability within the period of record. The annual mean streamflow of 477 cubic feet per second during 1977 was the smallest of record. Annual mean streamflow for the study

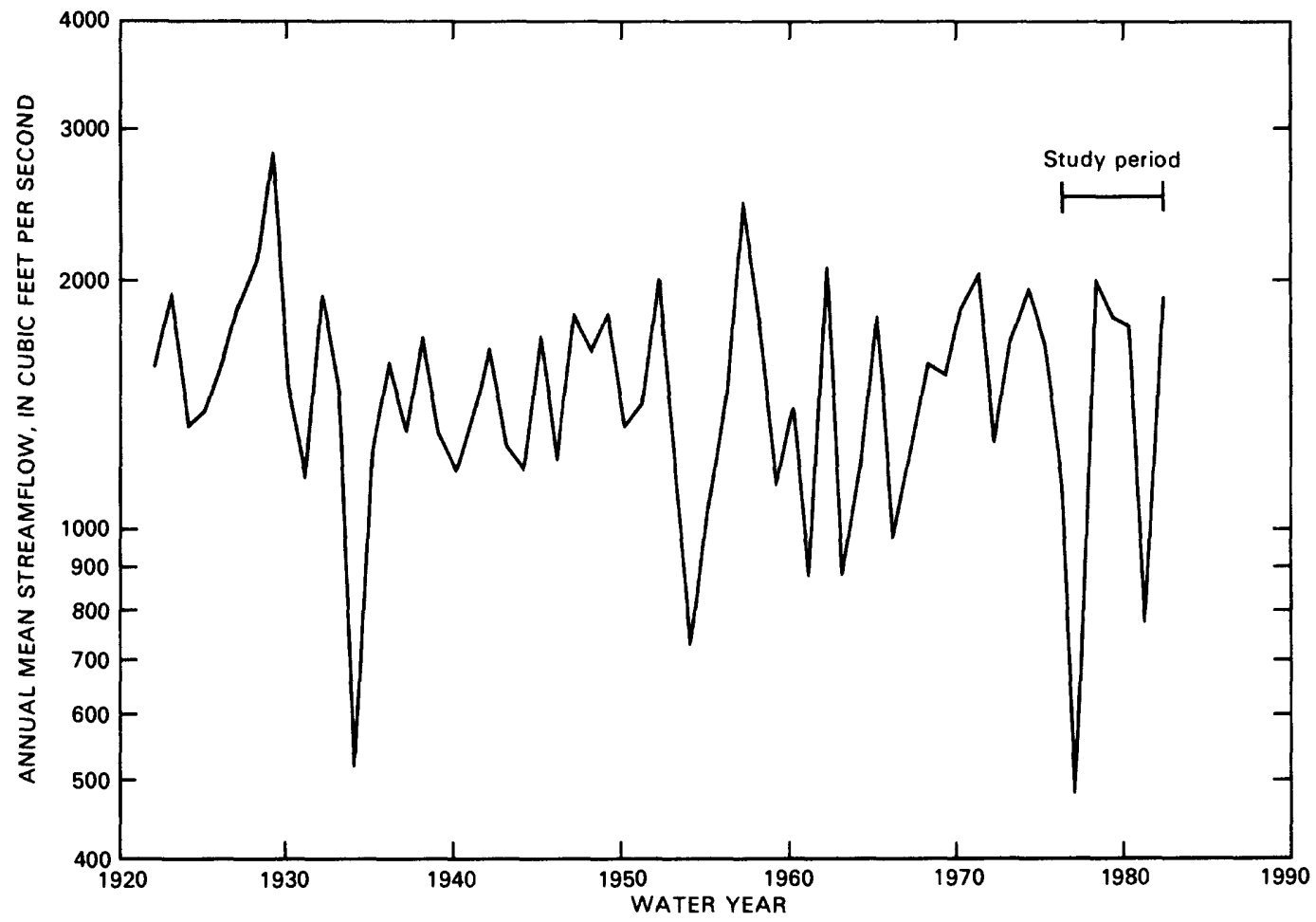

Figure 2.--Annual mean streamflow for Yampa River near Maybel1 (09251000), water years 1922-82. 
period was 86 percent of the annual mean streamflow for the period of record. Thus, the study period is somewhat analogous to the period of record with respect to streamflow. More importantly, the study period encompasses both high and low annual streamflows. This variety of streamflow provides an opportunity to examine dissolved-solids concentrations within almost the total range of streamflow conditions found in this river system.

\section{THE MODEL}

The model used in this report is the one used by Parker and Norris (1983) on Trout Creek, a tributary to the Yampa River. This model is an accounting method that sums water quantity and quality among points on a river system and provides an adequate framework given the lack of data in parts of the basin.

The model sums water quantity and quality in monthly time steps from one or more upstream points to a downstream point. The calculation of water quantity and quality is done at points called nodes. A stream segment or segments between nodes are defined as a reach. In the stream system studied, 72 nodes were used. The changes in water quantity and quality are attributed to the reach upstream from any particular node. As an example, a simple stream network with a series of nodes and node numbers is shown in figure 3 . If the concentration in dissolved solids is increased at node 5 , this increase is not necessarily because of a point source at node 5 but may be caused by diffused sources of water with a large dissolved-solids concentration in the reach bounded by nodes 1 to 5 and 4 to 5 .

There are three kinds of nodes: input, internal, and output. Input nodes are those at the upstream limits of the stream network (nodes 1,2 , and 3 in fig. 3). Because the summation process of water is in a downstream direction, calculations start at these nodes; therefore, the ideal situation is to have streamflow-gaging stations coincide with input nodes. This is not always possible; thus, estimated data need to be used.

Internal nodes (nodes 4, 5, and 6 in fig. 3) accumulate streamflow and dissolved solids from upstream nodes. Because the model sums quantity and quality of immediate upstream nodes and transfers the results to the node without routing the flow, the location of the internal nodes is relative only to the changes in the reach, not the distance. Internal nodes can be used to input real or proposed changes in water quantity and quality within the upstream reach. These changes at a node can be attributed to point sources of water from dewatering activities or diffused sources of water such as drainage from a coal-spoil pile. For brevity, proposed changes of water quantity and quality for several adjacent mines can be combined at a single node. In this report, no internal nodes representing individual coal mines are used. Nodes of this type can be inserted as needed in the calibrated model.

An output node is any node at which there is an interest in determining the model estimates through time. In the calibration phase, these nodes are located at data-collection sites where comparisons of measured data and calculated results are made. In the estimation phase, these nodes are located immediately downstream from areas of interest. The estimates are made by examining differences between present and anticipated mining activities. The 


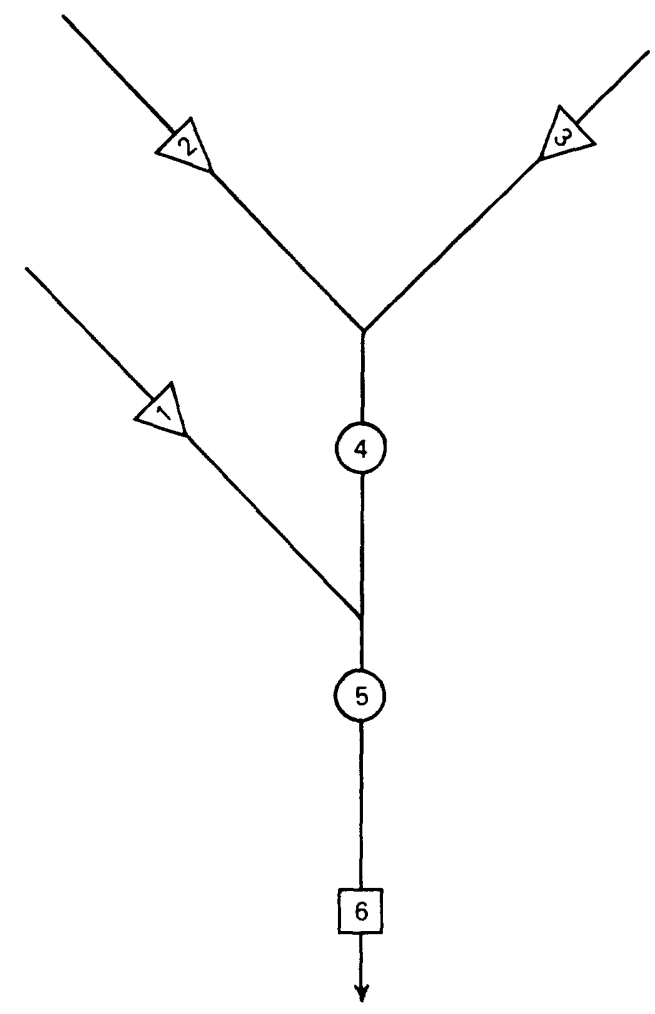

Figure 3.--Simple stream network with nodes and node numbers for the model.

most downstream node (node 6 , fig. 3) usually would be an output node. If the cumulative effects of coal mining in the area upstream from node 4 (fig. 3 ) are of interest, node 4 also could be an output node.

At any node, the surface-water-quantity component, which is mean monthly streamflow, in cubic feet per second, is calculated by the equation:

$$
Q_{i}=\left(\sum_{u=1}^{n} Q_{u}\right)+Q_{r}
$$

where $Q_{i}=$ streamflow at node $i$;

$\mathrm{n}^{\mathrm{i}}=$ number of adjacent nodes immediately upstream from node $i$;

$Q_{u}=$ streamflow at adjacent nodes immediately upstream from node $i$; and

$Q_{r}^{u}=$ incremental streamflow (increase or decrease) within the reach between node $i$ and adjacent nodes immediately upstream. 
The incremental streamflow within the reach $\left(Q_{r}\right)$ includes streamflow changes resulting from such situations as ungaged tributaries, ground water, diversions, and evapotranspiration. The estimate of incremental streamflow within the reach can be obtained from measured data or by estimating the data using the equation:

$$
Q_{r}=a+b Q_{s}
$$

where $Q_{r}=$ incremental streamflow (increase or decrease) within the reach;

$a$ and $b=$ the regression coefficients from simple linear regression; and

$$
Q_{s}=\text { streamflow at some nearby streamflow-gaging stations. }
$$

In the model, several stream reaches have both an upstream and a downstream node with a streamflow-gaging station. In these situations, $Q_{r}$ could be measured directly and observed streamflow data were used. In those situaions where measured data were not available, $Q_{r}$ initially was set to zero and then modified by altering the regression coefficients in equation 2 during calibration.

At each node the surface-water-quality component, monthly mean dissolved-solids concentration in milligrams per liter, is calculated by the mass-balance equation:

$$
C_{i}=\left[\left(\sum_{u=1}^{n} Q_{u} C_{u}\right)+Q_{r} C_{r}\right] /\left[\left(\sum_{u=1}^{n} Q_{u}\right)+Q_{r}\right],
$$

where $C_{i}=$ dissolved-solids concentration at node $i$;

$\mathrm{n}=$ number of nodes immediately upstream from node $i$;

$Q_{u}=$ streamflow at nodes immediately upstream from node $i$;

$\mathrm{C}_{\mathrm{u}}=$ dissolved-solids concentration at nodes immediately upstream from node $i$; and

$C_{r}=$ dissolved-solids concentration associated with the incremental streamflow $\left(Q_{r}\right)$ within the reach.

The dissolved-solids concentration associated with the incremental streamflow within the reach $\left(C_{r}\right)$ is obtained from the power form of the regression equation:

$$
C_{r}=e Q_{r}^{f}
$$

where $e$ and $f=$ the regression coefficients from simple linear regression.

Initial estimates of $C_{r}$ may be obtained from measured data at a node. For input nodes, the measured data are the actual values of $C_{r}$ because it is the integrated dissolved-solids concentration for the total reach above that 
node. That is, in equations 1 and $3, Q_{u}$ is equal to zero. However, for internal and output nodes, measured data indicate integrated dissolved-solids concentration for the total length of stream above the node but do not indicate $C_{r}$ in the reach between nodes. Thus, the measured data are not a direct estimate of $C_{r}$ if $Q_{r}$ is unknown. To estimate $C_{r}$ directly, streamflow $\left(Q_{i}\right)$ and concentration $\left(C_{i}\right)$ must be known at two adjacent nodes. Because data generally are not available to estimate $C_{\mathbf{r}}$ directly, final estimates of the regression coefficients in equation 4 were obtained during the calibration process. An assumption made in accounting for the dissolved solids in the above method is that the substance (dissolved solids) is conservative.

One special case needs to be discussed. In several stream segments water is lost between the upstream and downstream nodes during certain times of the year. If the streamflow at the upstream node or nodes is greater than the streamflow at the next node downstream (that is, if $Q_{r}<0$ ), then the concentration of dissolved solids is expected to be unchanged. However, evaporation or some other process, such as diversions for irrigation or mining operations and partial return of this water, can change the dissolved-solids concentration. The selected approach in computing the dissolved-solids concentration is to assume the concentration of the water lost is zero and to compute a resulting dissolved-solids concentration based on a calibration coefficient that is determined from data. The equation is:

$$
C_{i}=\left[\frac{Q_{i}}{\sum_{u=1}^{n}}\right] \cdot E_{i} \cdot\left[\sum_{u=1}^{n} Q_{u} C_{u}\right] /\left[\left(\sum_{u=1}^{n} Q_{u}\right)+Q_{r}\right]
$$

where $E_{i}=$ calibration coefficient for node $i \geq 1.0$.

Water-resource information is transferred and combined downstream from node to node. This type of transfer indicates the assumption that the time steps in the model are larger than the average traveltime among the nodes or within the reach. Further, the overall model is dependent on the assumption that the model time steps (months) are greater than the average traveltime within the basin. A study of traveltime in selected tributaries within several reaches of the Yampa main stem (N.E. Spahr, U.S. Geological Survey, written commun., 1985) shows that in all examples studied, the traveltime within the basin is well within the model time steps. 
The stream network is defined using 72 nodes. In general, input nodes were established on all the major tributaries to the Yampa River, at the most upstream point where data were available. Nodes also were established on minor tributaries in areas of particular interest. Internal nodes were established at the mouths of each major tributary and at points downstream from important confluences. In many instances, these nodes are not intended to reflect the hydrologic conditions upstream but merely accumulate information from input nodes.

Available water-resource information for input and output nodes in the model is listed in table 1 . In most cases, the nodes coincide with stations, but in some cases, nearby stations are used as the source of data. All nodes used in the model are shown in a schematic network of the Yampa stream system (fig. 4).

Water-resource information is needed at input nodes to initiate the routing process and at several output nodes to calibrate the model. The best source of information is data from a streamflow-gaging station for the time period during which the model runs. If this source is not available, the next best source of information is to have a streamflow-gaging station even though the record is not concurrent with the time period during which the model runs. The record can be estimated directly by a relation developed with another streamflow-gaging station using linear regression techniques.

In several instances, a streamflow-gaging station was not available for use, but there are instantaneous values that have been measured periodically on a scheduled and unscheduled basis. In such circumstances, a regression equation is developed between these instantaneous values and concurrent values at a nearby representative streamflow-gaging station. It is assumed that the monthly mean values at the two locations would follow this relation. The monthly values at the ungaged location are computed by using the monthly values from the streamflow-gaging station and this regression equation.

At many nodes, only periodic measurements are available, but these measurements were obtained within one season during synoptic water-quality investigations (Maura, 1982; Maura, 1985). Because these values were obtained during one part of the year, it was concluded that sufficient data were not available to adequately define the regression equations within the context of the assumption of transfer from instantaneous to monthly values. Thus, a ratio between each periodic measurement and concurrent value at the index streamflow-gaging station was computed and a mean value of all ratios was used as a multiplier to obtain monthly values at this node.

In the sections that follow, the node system is described, data and equations'for input nodes are shown, data available for internal nodes are shown, and data and equations needed at output nodes for calibration are given. Estimates needed for streamflow at input nodes are given, and the regression equations for the relation between dissolved-solids concentrations and streamflow in the form of equation 4 are shown. Each of these categories of data needs is discussed in downstream order and is organized by major tributaries. 


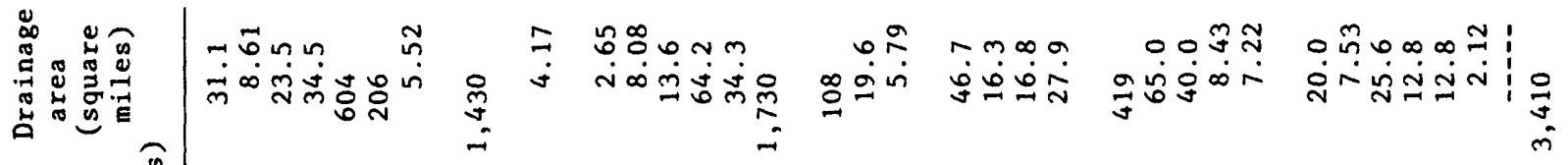

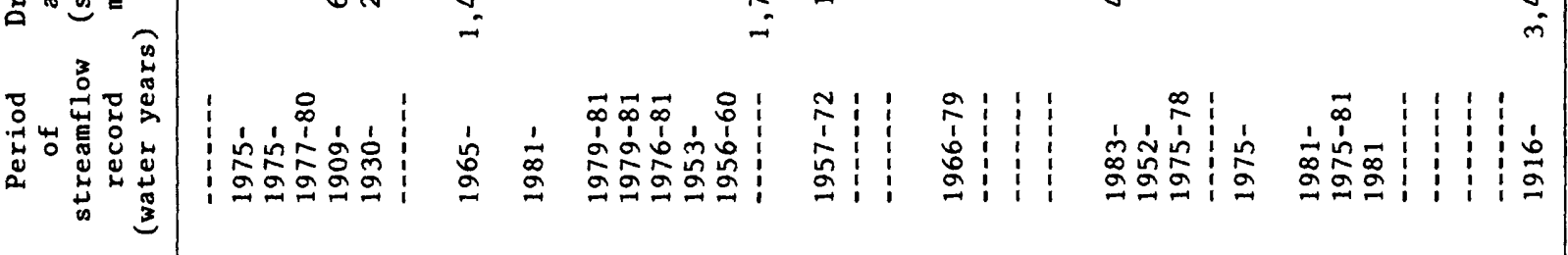

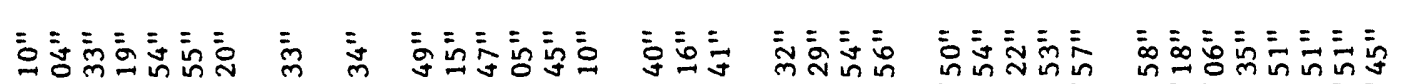

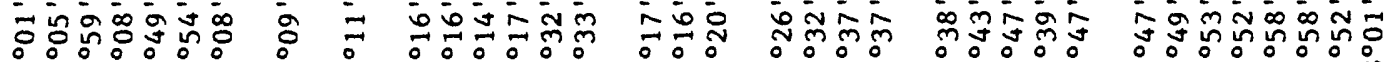

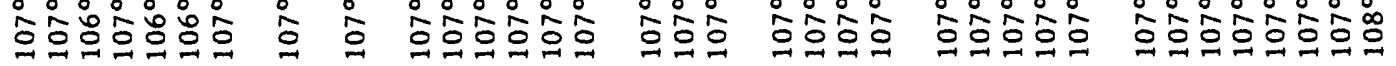

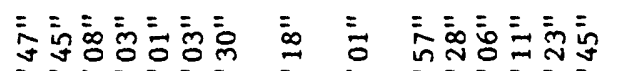

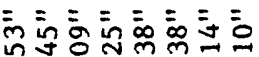

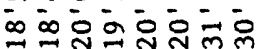
号宁

\%웡

\%웅

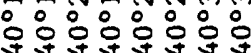

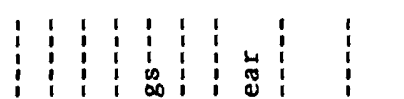

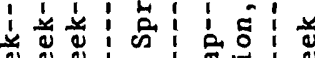

\section{矛芯}

( )

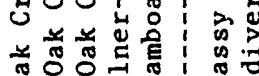

势

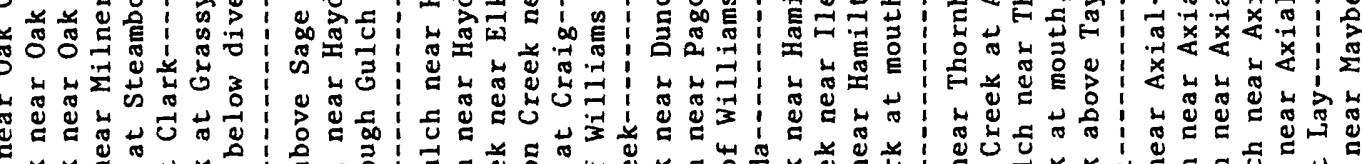

: :

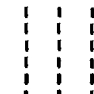

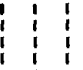

ว 4 ก

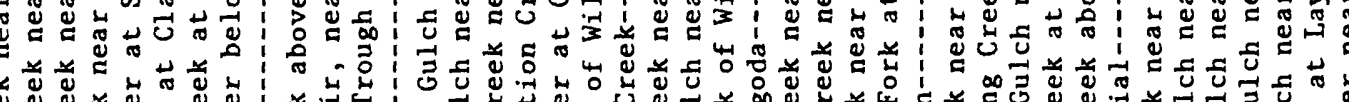

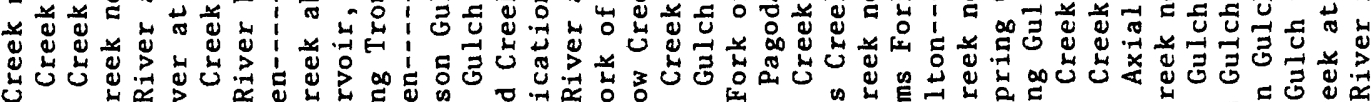

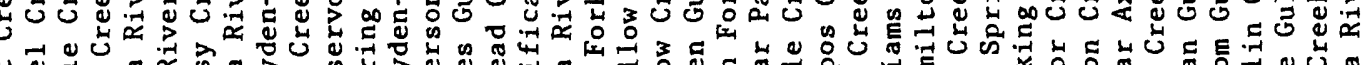

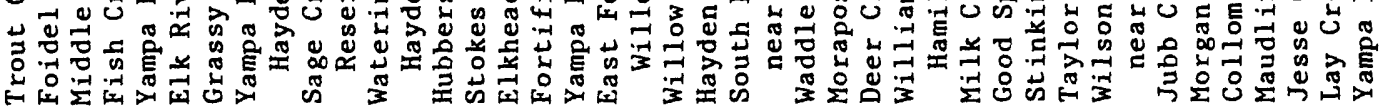

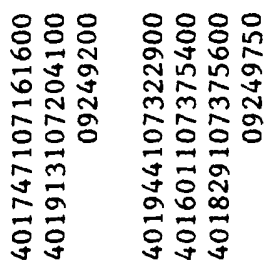

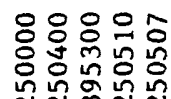

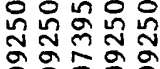

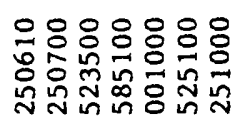

oㅇㅇㅇㅇㅇㅇㅇㅇㅇㅇㅇ

可点

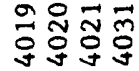

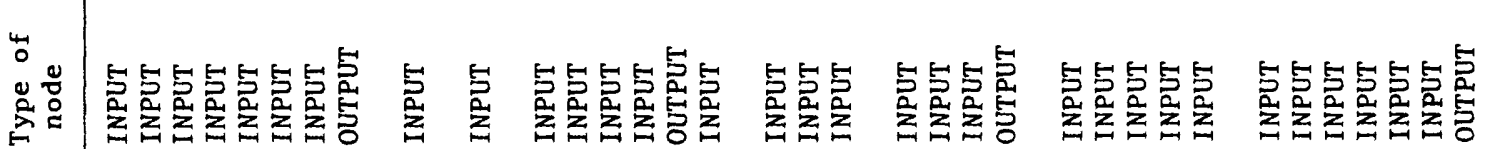
苋 


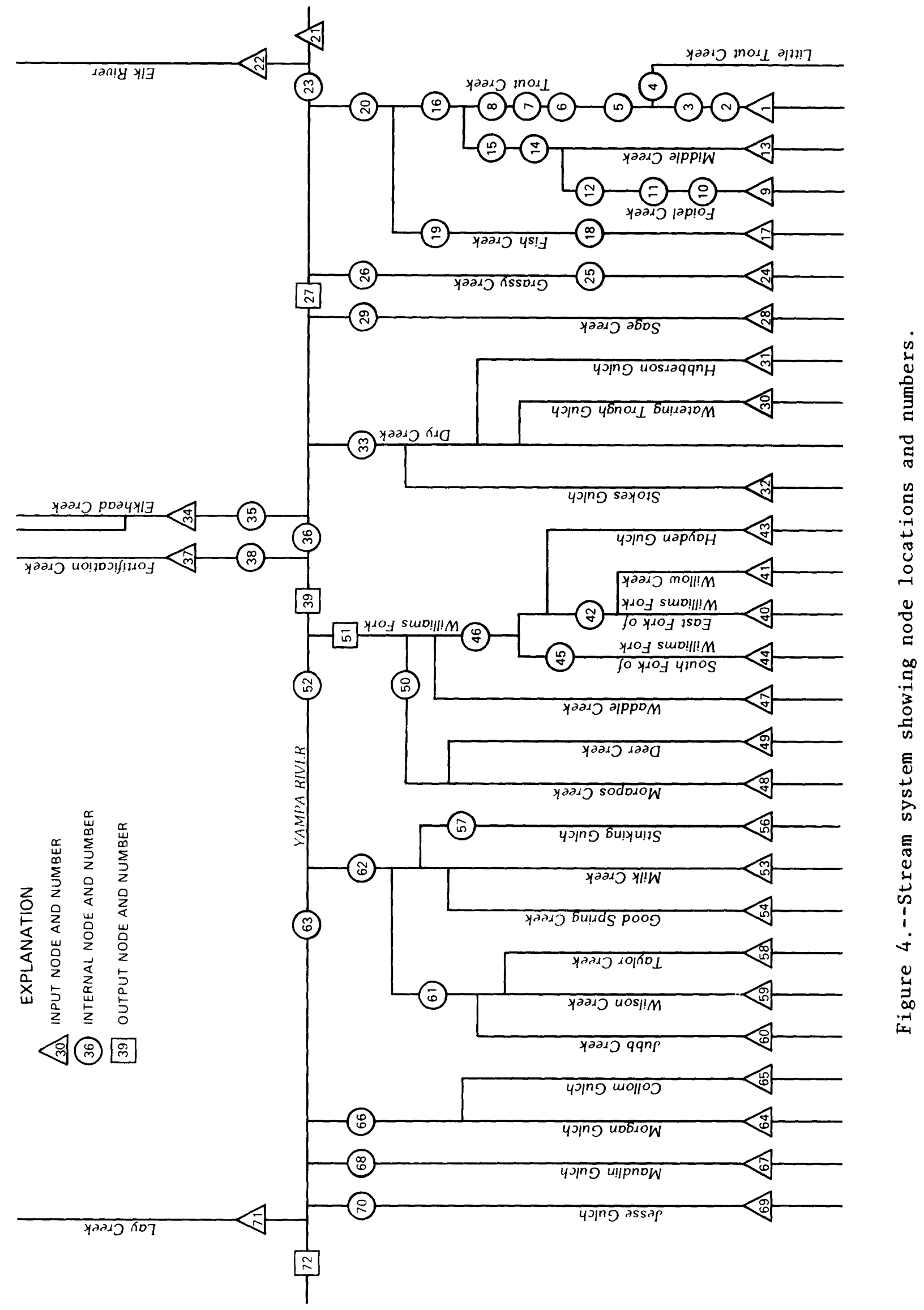


DATA USED IN MODEL

\section{Yampa River from Steamboat Springs to Hayden (nodes 1 to 27)}

This part of the node system and the associated data base were described in Parker and Norris (1983), and the streamflow estimates defined in that report are used here. This part includes the Yampa River from Steamboat Springs to the streamflow-gaging station upstream from Hayden, the major tributaries in this reach, Elk River and Trout Creek, and one smaller tributary, Grassy Creek. Node 27 was the final output node in Parker and Norris (1983). Data for this node are from the streamflow-gaging station, Yampa River below diversion near Hayden (09244410). Regression equations for the dissolved-solids concentration for the input nodes were obtained from the previous report (Parker and Norris, 1983, p. 13) and are reproduced here in table 2 for the input nodes $1,9,13,17,21,22$, and 24 .

\section{Sage Creek and Dry Creek (nodes 28-33)}

This section describes the node system for Sage Creek and Dry Creek. These two streams drain an area of generally low relief south and east of Hayden.

The only streamflow-gaging station on Sage Creek is Sage Creek above Sage Creek Reservoir near Hayden (09244415). The continuous streamflow record began during May 1981. This station coincides with input node 28. Missing streamflow record on this stream was estimated as being equivalent to Hubberson Gulch near Hayden (09244464), based on comparison of 11 concurrent measurements from 1981-82, and on monthly mean streamflow comparison from May through September of 1981. Dissolved-solids data collected at the Sage Creek streamflow-gaging station were used to derive the relation between streamflow and dissolved solids for node 28 (table 2). Internal node 29 was established at the mouth of Sage Creek. Although changes undoubtedly occur from the input node to the mouth of Sage Creek, water-quantity and water-quality data derived for the input node are transferred directly to the node at the mouth of the creek.

Most tributaries of Dry Creek have streamflow-gaging stations or miscellaneous sites where streamflow is measured. The tributaries are Watering Trough, Hubberson, and Stokes Gulches. Streamflow for the input nodes used in this report (table 1) are the ones described in Parker and Norris (1983, p. 44-59). Water-quality data collected at these streamflow-gaging stations were used to derive the regression equations for dissolved solids (table 2). No data are available for the node at the mouth of Dry Creek (node 33), and, therefore, the values from upstream are summed at this node.

\section{E1khead Creek and Fortification Creek (nodes 34-39)}

Elkhead and Fortification Creeks flow into the Yampa River downstream from Dry Creek. Both streams flow from the north, deriving most of their streamflow from snowmelt in the Elkhead Mountains. Each basin encompasses more than 240 square miles, yet streamflow information for drainage areas larger than 65 square miles is not available for either basin. Thus, data are available only for the upper quarter of these basins. Downstream in both 
Table 2.--Linear-regression equations of the logarithm of instantaneous streamflow and dissolved-solids concentrations for input nodes

$[C=$ dissolved-solids concentration, in milligrams per liter; $Q=$ instantaneous streamflow, in cubic feet per second]

\begin{tabular}{|c|c|c|c|c|}
\hline $\begin{array}{l}\text { Node } \\
\text { number }\end{array}$ & $\begin{array}{c}\text { U.S. Geological } \\
\text { Survey station } \\
\text { number }\end{array}$ & $\begin{array}{l}\text { Dissolved- } \\
\text { solids } \\
\text { concentration }\end{array}$ & $\begin{array}{c}\text { Number } \\
\text { of } \\
\text { paired } \\
\text { measurements }\end{array}$ & $\begin{array}{c}\text { Standard } \\
\text { error } \\
\text { (percent) }\end{array}$ \\
\hline $\begin{array}{r}1 \\
9 \\
13 \\
17 \\
21\end{array}$ & $\begin{array}{r}401816107011000 \\
09243800 \\
09243700 \\
09244100 \\
09239500\end{array}$ & $\begin{array}{l}C=283 Q_{-0.336}^{-0.336} \\
C=411 Q_{-0.098} \\
C=383 Q_{-0.238} \\
C=501 Q_{-0.38} \\
C=956 Q^{-0.30}\end{array}$ & $\begin{array}{r}6 \\
32 \\
50 \\
8 \\
(1)\end{array}$ & $\begin{array}{r}17 \\
70 \\
21 \\
24 \\
(1)\end{array}$ \\
\hline $\begin{array}{l}22 \\
24 \\
28 \\
30 \\
31\end{array}$ & $\begin{array}{r}09241000 \\
402330107082000 \\
09244415 \\
09244460 \\
09244464\end{array}$ & $\begin{array}{ll}109 & Q-0.15 \\
324 & Q-0.205 \\
333 & Q-0.168 \\
575 & Q-0.040 \\
550 & Q-0.183\end{array}$ & $\begin{array}{r}(1) \\
7 \\
22 \\
23 \\
26\end{array}$ & 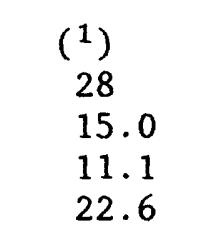 \\
\hline $\begin{array}{l}32 \\
34 \\
37 \\
40 \\
41\end{array}$ & $\begin{array}{r}09244470 \\
09245000 \\
403839107275000 \\
09248600 \\
401747107161600\end{array}$ & $\begin{array}{l}C=4,856 Q_{-0.256}^{-0.257} \\
C=275 Q_{-}=0.220 \\
C=360 Q-0.193 \\
C=254 Q_{-0.092} \\
C=322 Q\end{array}$ & 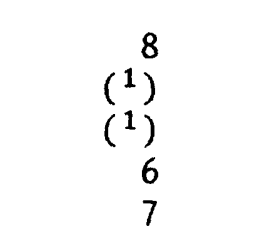 & $\begin{array}{l}40.2 \\
\left(\begin{array}{l}1 \\
1\end{array}\right) \\
\left(\begin{array}{l}1 \\
10.3 \\
7.3\end{array}\right.\end{array}$ \\
\hline $\begin{array}{l}43 \\
44 \\
47 \\
48 \\
49\end{array}$ & $\begin{array}{r}401913107204100 \\
09249200 \\
401944107322900 \\
401601107375400 \\
401829107375600\end{array}$ & $\begin{array}{l}C=779 Q_{-}^{-0.110} \\
C=279 Q_{-}=0.207 \\
C=490 Q-0.074 \\
C=469 Q_{-0.234} \\
C=903 Q^{-0.353}\end{array}$ & $\begin{array}{r}8 \\
(1) \\
8 \\
12 \\
11\end{array}$ & 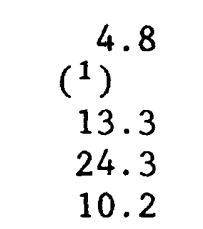 \\
\hline $\begin{array}{l}53 \\
54 \\
56 \\
58 \\
59\end{array}$ & $\begin{array}{r}09250000 \\
09250400 \\
401601107395300 \\
09250510 \\
09250507\end{array}$ & $\begin{array}{l}C=728 Q_{0}^{-0.193} \\
C=1,046 Q_{-0.107} \\
C=1,151 Q_{-0.424} \\
C=0.049 \\
C=1,139 Q^{-0.182}\end{array}$ & $\begin{array}{r}(1) \\
17 \\
16 \\
28 \\
54\end{array}$ & $\begin{array}{l}\left({ }^{1}\right) \\
9.6 \\
35.6 \\
32.8 \\
11.0\end{array}$ \\
\hline $\begin{array}{l}60 \\
64 \\
65 \\
67 \\
69 \\
71\end{array}$ & $\begin{array}{r}09250110 \\
09250700 \\
401925107523500 \\
402038107585100 \\
402145108001000 \\
403114107525100\end{array}$ & 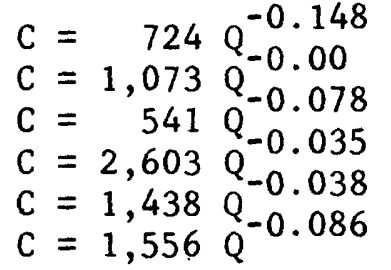 & $\begin{array}{r}38 \\
10 \\
8 \\
8 \\
7 \\
3\end{array}$ & $\begin{array}{r}24.2 \\
8.2 \\
4.6 \\
2.5 \\
4.5 \\
0.03\end{array}$ \\
\hline
\end{tabular}

${ }^{1}$ Equations are estimated from the linear-regression equations of the streamflow and the logarithm of specific conductance. See text for further discussion. 
basins, small reservoirs modify water quantity and quality but to an unknown extent.

Only one site on Elkhead Creek has continuous streamflow data concurrent with the study period (Elkhead Creek near Elkhead 09245000), although several other sites have data from previous years (table 1). This station has a drainage area of 64.2 square miles and is directly upstream from the tributary, North Fork Elkhead Creek. The North Fork has a discontinued streamflowgaging station and a drainage area of 21.0 square miles. Data were derived for the station on the North Fork and summed with the available data in the main stem of the Elkhead to yield values for the input node.

Streamflow for the North Fork Elkhead Creek near Elkhead (09245500) were estimated for the study period by regression equations developed between this station and the Elkhead Creek station (09245000) for the 15 years of concurrent record of monthly mean streamflow. Input node 34 for Elkhead Creek was established immediately downstream from the confluence of the North Fork and Elkhead Creek. Streamflow was calculated as the sum of the estimated North Fork streamflow (see table 8 in the "Supplemental Data" section at back of report) plus the measured Elkhead Creek near Elkhead streamflow. This Elkhead Creek input node has a drainage area of 85.2 square miles, which is about one-third the total basin area of the creek.

Data at the streamflow-gaging station Elkhead Creek near Elkhead (09245000) include 36 measurements of specific conductance and instantaneous discharge. It is assumed that dissolved solids are related to specific conductance (Hem, 1970; Parker and Norris, 1983, p. 15) by:

$$
\mathrm{S}=0.60 \mathrm{~K}
$$

where $S=$ dissolved-solids concentration, in milligrams per liter; and

$\mathrm{K}=$ specific conductance, in microsiemens per centimeter at $25{ }^{\circ} \mathrm{C}$.

Then, the equation for predicting dissolved solids from streamflow is as shown in table 2 for node 34 . This same technique was used for other nodes and noted in table 2 .

Node 35 was established at the mouth of Elkhead Creek. The drainage area at node 35 is 249 square miles. The quantity and quality of water in the stream undoubtedly is different from that of node 34 because of routing of the water through Elkhead Reservoir, but a lack of data in the downstream reaches of the stream prevents a determination. It is assumed the water quantity and quality at the upstream node (node 34 ) can be routed directly to the outlet of Elkhead Creek (node 35) without modification.

Fortification Creek is the next major drainage west of Elkhead Creek. It generally flows south and drains an area north of Craig. The streamflowgaging station, Fortification Creek near Craig (09246900), has 5 years of streamflow data prior to the study period (table 1). These data are concurrent with records from Elkhead Creek near Elkhead (09245000). Monthly regression relations (see table 9 in the "Supplemental Data" section at back of report) were developed between these two stations to provide a means of 
calculating a data set of streamflow for Fortification Creek near Craig (09246900). This was established as input node 37 . No dissolved-solids data are available for this node (node 37 ), and a water-quality sampling site, Fortification Creek above Ralph White Lake (403839107275000), located about 7 miles downstream, is used (table 2). Undoubtedly, some changes in the water chemistry have occurred in this 7 -mile reach of the stream, but this site is upstream from the effects of the reservoir and the city of Craig. Only specific-conductance values are available at this site, and equation 6 is assumed to be a reasonable conversion to dissolved-solids concentration.

Sufficient data are not available near the mouth of Fortification Creek at the confluence with the Yampa River. A node is established near the mouth of Fortification Creek (node 38 ), and the water quantity and quality from the upstream node is routed to this node.

The data-collection station, Yampa River at Craig (09247500), is located downstream from Elkhead, Fortification, and Dry Creeks, and, therefore, the data reflect changes caused by the inflow of water from these tributaries. Monthly water-quality samples and streamflow measurements were collected at this station during the study period and, therefore, provide a data set for calibration purposes. This station was established as output node 39 . Only instantaneous values of streamflow are available at this station. To derive monthly mean values of streamflow, the streamflow measurements made at this station were compared to the corresponding daily mean streamflow at the upstream streamflow-gaging station, Yampa River below diversion near Hayden (09244410). The resulting ratio was multiplied by the monthly mean streamflow at the upstream streamflow-gaging station to provide monthly mean values for the streamflow-gaging station, Yampa River at Craig (09247500). Water-quality values (table 3 ) were computed by a linear regression equation that was developed from 59 measurements of streamflow and dissolved-solids concentration.

\section{Williams Fork (nodes 40-51)}

The next major downstream tributary to the Yampa River is the Williams Fork. It is comparable in drainage area to the Elk River; however, the streamflow is only one-half that of the Elk River. Upstream, the Williams Fork divides into two tributaries--the East and South Forks. The East Fork is the largest, having a streamflow about three times that of the South Fork. Hayden Gulch and Willow Creek are both small tributaries of the East Fork. Waddle and Morapos Creek are tributaries to Williams Fork.

Input node 40 for the East Fork Williams Fork was established at East Fork Williams Fork, above Willow Creek (09248600). Continuous streamflow data are available from 1957 through 1972 (table 1). Streamflow for this node for the study period was calculated for each month by regression equation (see table 10 in the "Supplemental Data" section at back of report) with the streamflow-gaging station in the White River basin south of Thornburgh, White River above Coal Creek near Meeker (09304200). Dissolved-solids data are available for this East Fork station, but a dissolved-solids relation with streamflow was established to provide data in the necessary format (table 2). 
Table 3.--Linear-regression equations of the logarithm of instantaneous streamflow and dissolved-solids concentrations for output nodes

$[C=$ dissolved-solids concentration in milligrams per liter; $\mathrm{Q}=$ instantaneous streamflow, in cubic feet per second]

\begin{tabular}{lcccc} 
Node & $\begin{array}{c}\text { U.S. Geological } \\
\text { number }\end{array}$ & $\begin{array}{c}\text { Dissolved } \\
\text { solids } \\
\text { number }\end{array}$ & $\begin{array}{c}\text { Number } \\
\text { of } \\
\text { concentration } \\
\text { paired } \\
\text { measurements }\end{array}$ & $\begin{array}{c}\text { Standard } \\
\text { error } \\
\text { (percent) }\end{array}$ \\
\hline 39 & 09247500 & $C=497 Q^{-0.280}$ & 59 & 37.3 \\
51 & 09249750 & $C=607 Q^{-0.209}$ & 57 & 28.5 \\
72 & 09251000 & $C=1,796 Q^{-0.310}$ & 66 & 33.4 \\
\hline
\end{tabular}

Input nodes were established on two tributaries to the East Fork Williams Fork--Willow Creek (node 41) and Hayden Gulch (node 43). Input node 41 was established on Willow Creek using data from the site, Willow Creek near Dunckley (401747107161600) (table 1). This site has seven streamflow measurements. Given the small number of measurements, ratios were developed with concurrent streamflows at the streamflow-gaging station, Milk Creek near Thornburgh (09250000). These ratios ranged from 0.08 to 0.36 , and the mean value was used in the equation:

$$
Q_{p_{41}}=0.23 Q_{O_{53}}
$$

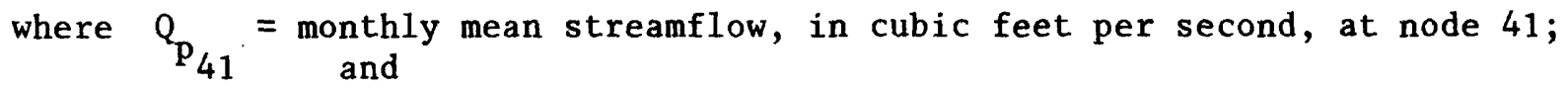

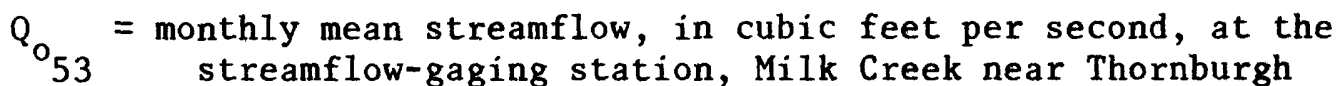
(09250000).

The relation between streamflow and dissolved solids was determined from seven samples collected at the site (table 2).

Input node 43 was established on Hayden Gulch using data from the site Hayden Gulch near Pagoda (401913107204100) (table 1). Streamflow data were estimated based on comparison of five concurrent measurements from this site and measurements from the streamflow-gaging station, Hubberson Gulch near Hayden (09244464). The mean value of these ratios was used in the equation:

$$
\mathrm{Q}_{43}=0.72 \mathrm{Q}_{\mathrm{o}_{31}}
$$

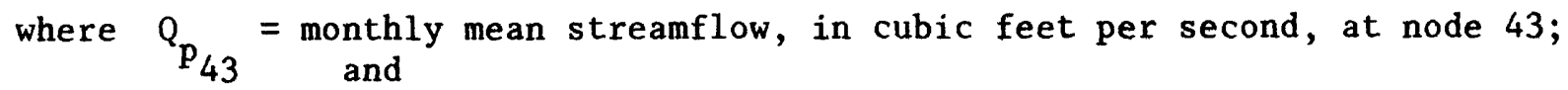

$\mathrm{Q}_{\mathrm{O}_{31}}=$ monthly mean streamflow, in cubic feet per second, at the
streamflow-gaging station, Hubberson Gulch near Hayden (09244464). 
A relation between streamflow and dissolved solids was determined from eight samples from the site on Hayden Gulch (table 2).

Input node 44 for the South Fork Williams Fork used data from the streamflow-gaging station, South Fork of Williams Fork, near Pagoda (09249200). This station has streamflow data concurrent with part of the study period (table 1). Missing flow data for the 1980 and 1981 water years were calculated by monthly regression (see table 11 in the "Supplemental Data" section at back of report) with the streamflow-gaging station, White River above Coal Creek near Meeker (09304200). The water-quality relation with streamflow was calculated from 17 measurements of streamflow and specific conductance at the South Fork Williams Fork streamflow-gaging station. The relation between specific conductance and streamflow was developed first. The specific conductance was used to compute dissolved solids by equation 6 (table 2).

Downstream on the Williams Fork from South Fork Williams Fork there are two additional tributaries. Waddle Creek is a small stream that drains from the south. Morapos Creek is a larger tributary farther downstream that has a tributary, Deer Creek. Input nodes were placed on Waddle, Morapos, and Deer Creeks. Each of these streams has a periodic-measurement site near the input node location. These sites have instantaneous streamflow measurements that can be compared with the only long-term streamflow-gaging station in the area, Milk Creek near Thornburgh (09250000).

Input node 47 was established on Waddle Creek using data from the site, Waddle Creek near Hamilton (401944107322900) (table 1). Streamflow was estimated from instantaneous streamflow values compared with 10 concurrent values from Milk Creek near Thornburgh (09250000). The ratio developed ranges from 0.02 to 0.14 , and the mean value is used in the equation:

$$
Q_{p_{47}}=0.12 Q_{o_{53}}
$$

where $Q_{p_{47}}=\begin{gathered}\text { predicted monthly mean streamflow, in cubic feet per } \\ \text { second, for node } 47 ; \text { and }\end{gathered}$

$\mathrm{Q}_{\mathrm{O}_{53}}=$ monthly mean streamflow, in cubic feet per second, for the streamflow-gaging station, Milk Creek near Thornburgh (09250000).

The equation derived for dissolved-solids concentration uses the data collected at the site on Waddle Creek (table 2).

Input node 48 was established on Morapos Creek upstream from the confluence with Deer Creek. Data from the water-quality site, Morapos Creek near Iles Grove (401601107375400), are used for this input node. Streamflow is estimated using 12 measurements of streamflow at this site and data from the Milk Creek streamflow-gaging station. This ratio ranges from 0.05 to 0.40 , and the mean value is used in the equation:

$$
Q_{p_{48}}=0.19 Q_{o_{53}}
$$


where $Q_{p_{48}}=\begin{gathered}\text { predicted monthly mean streamflow, in cubic feet per second } \\ \text { for node } 48 ; \text { and }\end{gathered}$

$\mathrm{Q}_{\mathrm{O}_{53}}=\begin{gathered}\text { monthly mean streamflow, in cubic feet per second, } \\ \text { for the streamflow-gaging station, Milk Creek }\end{gathered}$ near Thornburgh (09250000).

The relation derived for dissolved-solids concentration and streamflow for input node 48 used data from the site on Morapos Creek (table 2).

Input node 49 is on Deer Creek, a tributary to Morapos Creek. Waterresource data needed for this node were derived from data collected at the site, Deer Creek near Hamilton (401829107375600). Streamflow is estimated using 11 measurements of streamflow at this site and data from the Milk Creek streamflow-gaging station. This ratio ranges from 0.07 to 0.87 , and the mean value is used in the equation:

$$
Q_{p_{49}}=0.31 Q_{o_{53}}
$$

where $\mathrm{Q}_{\mathrm{p}_{49}}=$ predicted monthly mean streamflow, in cubic feet per second,

$\mathrm{Q}_{\mathrm{O}_{53}}=\begin{gathered}\text { monthly mean streamflow, in cubic feet per second, for the } \\ \text { streamflow-gaging station, Milk Creek near Thornburgh }\end{gathered}$ (09250000).

The equation between dissolved solids and streamflow, for input node 49, is derived from data from the site on Deer Creek (table 2).

Internal node 50 was established at the mouth of Morapos Creek, but no hydrologi= data were available. Thus, streamflow and dissolved solids are summed from the upstream input nodes on Morapos and Deer Creeks to this point without modification.

Output node 51 was established at the mouth of the Williams Fork. Waterresource data used for this node are from the streamflow-gaging station, South Fork of Williams Fork, near Pagoda (09249200), and the water-quality site Williams Fork at mouth, near Hamilton (09249750). The site at node 51 has considerable water-quality data but has only instantaneous streamflow measurements obtained approximately monthly. However, measured or estimated data are needed at node 51 for calibrating purposes.

Monthly mean streamflow data at the mouth of the Williams Fork are estimated by developing a relation between the site at node 51 and South Fork of Williams Fork, near Pagoda (09249200). There are 57 streamflow measurements near the mouth of the Williams Fork. These 57 measurements are compared to the concurrent mean daily streamflow values from the gaging station. The data base is not sufficient to provide monthly regression equations, but the data can be divided into a spring-summer season during the high-flow period and a fall-winter season during the low-flow period. For the fall-winter 
season, which includes September through February, 24 values are used to derive the equation for each month:

$$
\mathrm{Q}_{\mathrm{p}_{51}}=26.20+3.31 \mathrm{Q}_{\mathrm{w}_{44}}
$$

where $Q_{p}=$ predicted monthly mean streamflow for fall-winter months, in cubic feet per second, for node 51 ; and

$Q_{\mathrm{o}_{\mathrm{w}}}=$ monthly mean streamflow, for fall-winter months, in cubic
feet per second, for South Fork of Williams Fork, near Pagoda (09249200).

This equation has a standard error of 9.96 cubic feet per second and a R-squared value of 0.21 , which is significant at the 95-percent level.

The equation for the spring-summer season includes March through August and uses 26 data pairs. The equation is:

$$
\mathrm{Q}_{\mathrm{s}_{51}}=85.25+2.83 \mathrm{Q}_{\mathrm{o}_{44}}
$$

where $Q_{p} \quad=$ predicted monthly mean streamflow for spring-summer months, in cubic feet per second, for node 51 ; and

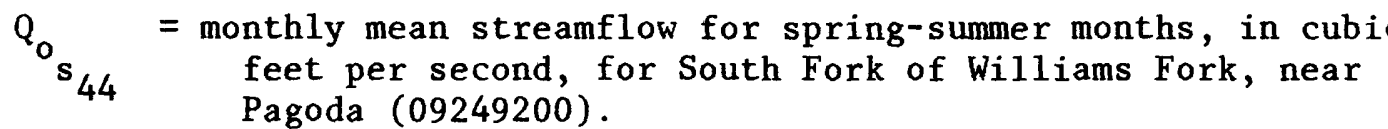

This relation has a standard error of 135.74 cubic feet per second and a $\mathrm{R}$-squared value of 0.91 , which is significant at the 95-percent level.

The relation between streamflow and dissolved-solids concentration was developed from 57 samples from Williams Fork at mouth near Hamilton (09249750), node 51 (table 3). Although streamflow is estimated for this node, the data sets developed here are used as the measured values for the node in order to evaluate model values during calibration. There is a significant error in the data set generated at this node and that error is difficult to transfer to the error analysis in calibration and to assess its effect on calibration. However, calibration at this node is desirable because it represents a sizable part of the south valley area of the Yampa River basin.

\section{Milk Creek (nodes 53-62)}

Milk Creek is the next downstream tributary to the Yampa River, and the creek drains an area adjacent to the Williams Fork. Good Spring Creek, Stinking Gulch, and Taylor, Wilson, and Jubb Creeks are tributary to Milk Creek. The headwaters of these streams drain the Danforth Hills. The downstream reaches of these tributaries drain the eastern part of the Axial basin, 
a low-lying structural feature near the Yampa River. These streams receive most of their streamflow from the Danforth Hills. The Axial basin is very dry, and, in general, the water from upstream is delivered across this basin and losses occur from evapotranspiration and seepage into the alluvium.

Milk Creek near Thornburgh (09250000) is important as a gaging station for streamflow, because it is the only station in this part of the Yampa basin that has long-term streamflow record (table 1). An input node (node 53) was established at this station on Milk Creek. Thus, streamflow data are available from the station record. The dissolved-solids relation (table 2) was obtained from streamflow and specific-conductance data and equation 6, which relates specific conductance to dissolved solids.

Input node 54 is on Good Spring Creek, and streamflow data used for this node are from the streamflow-gaging station, Good Spring Creek at Axial (09250400) (table 1). This station has streamflow data for the water years 1975 through March 1978. To estimate the additional streamflow record needed for the model, regression relations, using monthly mean streamflow, were developed with the streamflow-gaging station, Milk Creek near Thornburgh (09250000). Sufficient data were available to define equations for two seasons. The fall-winter season includes September through February. The regression equation is defined with 23 monthly mean values and has a standard error of 0.26 cubic foot per second and an R-squared value of 0.79 . The equation is :

$$
\mathrm{Q}_{\mathrm{w}_{54}}=0.13+0.30 \mathrm{Q}_{\mathrm{w}_{53}}
$$

$$
\begin{aligned}
& \text { where } Q_{p} \quad \text { predicted monthly mean streamflow, in cubic feet per second, } \\
& \text { for the fall-winter season for input node 54; and } \\
& Q_{0} \quad=\text { monthly mean streamflow, in cubic feet per second, for } \\
& \text { Milk Creek near Thornburgh (09250000). }
\end{aligned}
$$

The equation for the spring-summer season, which includes March through August, is defined with 17 data values, and has a standard error of 0.98 cubic foot per second and an R-squared value of 0.75 . The equation is:

$$
Q_{p_{s_{54}}}=0.92+0.003 Q_{o_{s_{53}}}
$$

where $Q_{p} \quad=$ predicted monthly mean streamflow, in cubic feet per second, for the spring-summer season, for input node 54; and

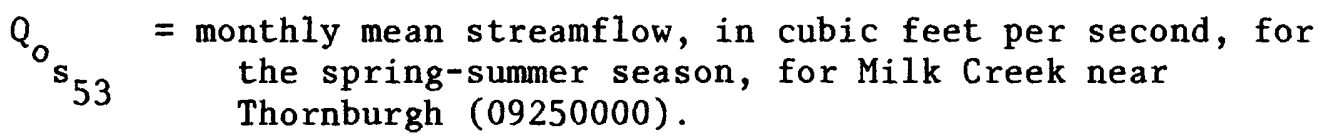


The relation between streamflow and dissolved-solids concentration for node 54 was derived from measurements at the streamflow-gaging station, Good Spring Creek at Axial (09250400) (table 2).

Internal node 55 was placed downstream on Milk Creek downstream from the confluence with Good Spring Creek. Water quantity and quality from the input nodes upstream are summed at this node. No modification was needed.

Input node 56 is on Stinking Gulch, and water-resource information was used from the site, Stinking Gulch near Thornburgh (401601107395300)

(table 1). Based on 16 concurrent streamflow measurements between Stinking Gulch near Thornburgh (401601107395300) and Milk Creek near Thornburgh (09250000), a ratio is developed for each and a mean obtained. This mean ratio is :

$$
\mathrm{Q}_{\mathrm{P}_{56}}=0.33 \mathrm{Q}_{\mathrm{o}_{53}}
$$

where $\quad Q_{p_{56}}=\begin{gathered}\text { predicted monthly mean streamflow, in cubic feet per second, } \\ \text { at node } 56 ; \text { and }\end{gathered}$

$$
\begin{aligned}
& \mathrm{Q}_{\mathrm{O}_{53}}=\text { monthly mean streamflow, in cubic feet per second, } \\
& \text { at Milk Creek near Thornburgh }(09250000) \text {. }
\end{aligned}
$$

This ratio varies from 0.05 to 0.87 among the measurements. The relation between dissolved-solids concentration and streamflow (table 2) was developed based on data measurements from Stinking Gulch near Thornburgh (401601107395300).

Internal node 57 was established at the mouth of Stinking Gulch. A few data values from two sites near this node indicate a substantial change in water quality and quantity from the upstream node on this creek. However, additional data are needed to modify water quantity and quality at this node. Thus, within the model, water quantity and quality are routed directly from upstream to this internal node without modification.

Streamflow data for input node 58 on Taylor Creek were from the streamflow-gaging station, Taylor Creek at mouth, near Axial (09250510). A relation between streamflow and dissolved solids for this station was developed (table 2) using data measurements from this same streamflow-gaging station.

The input node 59 on Wilson Creek uses streamflow data from the streamflow-gaging station, Wilson Creek above Taylor Creek near Axial (09250507), for the 1981 water year (table 1) and Wilson Creek, near Axial (09250600) for the water years 1976 through 1980. These two stations are immediately upstream from and downstream from the confluence with Taylor Creek. By subtracting the streamflow of Taylor Creek at mouth near Axial (09250510) from Wilson Creek near Axial (09250600), a complete data set for the period can be obtained for Wilson Creek above Taylor Creek near Axial (09250507), which coincides with input node 59. The relation between streamflow and dissolved-solids concentration (table 2) was developed using data from both Wilson Creek streamflow-gaging stations. 
Streamflow data for input node 60 on Jubb Creek were from the streamflow-gaging station, Jubb Creek near Axial (09250610) (table 1). A relation between streamflow and dissolved-solids concentration (table 2) was developed using data from this same streamflow-gaging station.

An internal node was established at Wilson Creek at mouth (node 61), but no data are available for calibration at this node. A similar situation exists for internal node 62 , Milk Creek near the mouth.

Yampa River Below Milk Creek to Yampa River near Maybell (nodes 63-72)

Small intermittent streams drain the western one-half of the Axial basin. Morgan, Collom, Maudlin, and Jesse Gulches drain parts of the Danforth Hills and convey this water across the Axial basin. Lay Creek is the principal southerly-flowing stream north of the Yampa River in this reach.

Input node 64 was established at the streamflow-gaging station at Morgan Gulch near Axial (09250700). Measured streamflow is used for water year 1981, the only year that data were collected. To estimate the remaining streamflow data, a comparison of the 10 available monthly mean streamflow values were compared with concurrent values from the streamflow-gaging station, Wilson Creek above Taylor Creek near Axial (09250507). Although these ratios range from 0.26 to 1.58 , the mean value is used, and the equation for this site is:

$$
Q_{p_{64}}=1.10 Q_{0_{59}}
$$

where $\quad Q_{p_{64}}=\begin{gathered}\text { predicted monthly mean streamflow, in cubic feet per second, } \\ \text { for node } 64 ; \text { and }\end{gathered}$

$$
\begin{gathered}
Q_{\mathrm{o}_{59}}=\text { observed monthly mean streamflow, in cubic feet per second, } \\
\text { for Wilson Creek above Taylor Creek near Axial (09250507). }
\end{gathered}
$$

The relation between streamflow and dissolved-solids concentration (table 2) was developed for this site based on data collected at the streamflow-gaging station, Morgan Gulch near Axial (09250700).

Input node 65 was established on Collom Gulch, which is a tributary to Morgan Gulch. Water-resource information for this node is from Collom Gulch near Axial (401925107523500) (table 1). Streamflow was based on a comparison with Wilson Creek above Taylor Creek near Axial (09250507), using eight concurrent measurements from the site on Collom Gulch. These ratios range from 0.07 to 1.4 . The mean value is used in the equation:

$$
Q_{p_{65}}=0.31 Q_{o_{59}}
$$
where $\quad Q_{p_{65}}=\begin{gathered}\text { predicted monthly mean streamflow, in cubic feet per second, } \\ \text { for input node } 65 ; \text { and }\end{gathered}$

$$
\begin{gathered}
Q_{o_{59}}=\text { monthly mean streamflow, in cubic feet per second, for } \\
\text { Wilson Creek above Taylor Creek near Axial (09250507). }
\end{gathered}
$$


The relation between streamflow and dissolved-solids concentration (table 2) was developed from the site, Collom Gulch near Axial (401925107523500).

Internal node 66 was established at the mouth of Morgan Gulch. Streamflow and dissolved-solids concentrations are accumulated directly from the upstream nodes.

Input node 67 was established on Maudlin Gulch using the water-resource data from the site, Maudlin Gulch near Axial (402038107585100) (table 1). Comparison with data from the streamflow-gaging station, Wilson Creek above Taylor Creek near Axial (09250507), and eight concurrent measurements at this site yields ratio values from 0.04 to 0.25 . The mean value is used in the equation:

$$
Q_{p_{67}}=0.17 Q_{0_{59}}
$$

where $\quad Q_{p_{67}}=\begin{gathered}\text { predicted monthly mean streamflow, in cubic feet per second, } \\ \text { for input node } 67 ; \text { and }\end{gathered}$

$$
\begin{array}{r}
Q_{o_{59}}=\text { monthly mean streamflow, in cubic feet per second, for } \\
\text { for Wilson Creek above Taylor Creek near Axial (09250507). }
\end{array}
$$

The relation between streamflow and dissolved-solids concentration (table 2) is based on data from the site, Maudlin Gulch near Axial (402038107585100).

Input node 69 was established on Jesse Gulch using water-resource information from the site, Jesse Gulch near Axial (402145108001000). From this site, seven streamflow measurements are available and are compared with the streamflow-gaging station, Wilson Creek above Taylor Creek near Axial

(09250507). These ratios range from 0.04 to 0.17 . The mean is used in the equation:

$$
Q_{p_{69}}=0.08 Q_{0_{59}}
$$

where $Q_{p_{59}}=\begin{gathered}\text { predicted monthly mean streamflow, in cubic feet per second, } \\ \text { for input node } 69 ; \text { and }\end{gathered}$

$\mathrm{Q}_{\mathrm{o}_{59}}=$ monthly mean streamflow, in cubic feet per second, for
Wilson Creek above Taylor Creek near Axial (09250507).

The relation between streamflow and dissolved-solids concentration for node 69 is computed from the site, Jesse Gulch near Axial (402145108001000) (table 2).

Input node 71 was established on Lay Creek and water-resource information was used from the site, Lay Creek at Lay (403114107525100) (table 1). Only three streamflow measurements are available at this site. They are compared 
to Wilson Creek above Taylor Creek near Axial (09250507). These three ratios range from 0.32 to 0.58 . The mean is used in the equation:

$$
Q_{p_{71}}=0.44 Q_{o_{59}}
$$

where $\quad Q_{p_{71}}=\begin{gathered}\text { predicted monthly mean streamflow, in cubic feet per second, } \\ \text { for input node } 71 ; \text { and }\end{gathered}$

$$
\begin{aligned}
& Q_{0_{59}}=\text { monthly mean streamflow, in cubic feet per second, } \\
& \text { for Wilson Creek above Taylor Creek near Axial (09250507). }
\end{aligned}
$$

The relation between streamflow and dissolved-solids concentration for node 71 is based on the data from the site, Lay Creek at Lay (403114107525100) (table 2).

The final node in the model is output node 72. Data for this node are from the streamflow-gaging station Yampa River near Maybel1 (092510000) (table 1). Measured streamflow data are available for the study period at this station. Daily specific-conductance values are available for most of the study period. Daily specific conductance and streamflow values were graphically compared. Periods of missing record were estimated using available specific conductance and streamflow data. Dissolved-solids concentrations then were calculated using the form of equation 6 and 66 data measurements from this site. The equation is:

$$
\mathrm{S}_{72}=0.637 \mathrm{~K}_{72}
$$

where $\mathrm{S}_{72}=$ predicted dissolved-solids concentration, in milligrams per liter, for node 72 ; and

$\mathrm{K}_{72}=$ specific conductance, in microsiemens per centimeter at $25{ }^{\circ} \mathrm{C}$, for Yampa River near Maybell (092510000).

The standard error for this relation is 20.2 milligrams per liter. The relation between instantaneous streamflow and dissolved-solids concentration in the form used throughout this study is shown in table 3. Monthly dissolved-solids loads then were calculated for the study period.

\section{MODEL CALIBRATION}

For calibration of the model, the errors were examined in the form:

$$
e=\frac{V_{o}-V_{p}}{V_{p}}
$$

where $e=$ error;

$\mathrm{V}_{\mathrm{o}}=$ one of the measured variables of streamflow, concentration, or load; and

$V_{p}=$ the same predicted variables of streamflow, concentration,

This form gives equal weight to low-flow and high-flow errors and seems reasonable because the emphasis of this study is not on any single part of the 
hydrologic regime. Calibration is for the entire study period. However, to assess some aspects of seasonal errors, the water year was separated into a high-flow season from April through June and a low-flow season from July through March. Error statistics were computed for the high-flow period, the low-flow period, and the combined-flow period.

The objective function used duxing calibration was the mean square error for the 72 months the model operated for each variable. The error function uses the logarithms of the differences between measured and predicted values in the form of equation 23. The mean square error is:

$$
\mathrm{MSE}=\overline{\mathrm{x}}^{2}+\mathrm{s}^{2}
$$

where $M S E=$ mean square error;

$\bar{x}=$ mean of the differences between the logarithms (base e) of measured and model prediction for each model variable for each month; and

$s^{2}=$ variance of the difference of the logarithms (base e) between the measured and model prediction for each model variable for each month.

In this equation, the first term is the bias from the true mean zero, and the second term is the variance. During calibration, the attempt was to reduce the bias $(\bar{x})$ to zero with a minimum variance $\left(s^{2}\right)$.

Because the error function is in the form of equation 23 and the error is divided into two components of bias and variance (eq. 24), the error, in percent, can be derived from Matalas (1967) as:

$$
\operatorname{Error}=\left(\mathrm{e}^{\overline{\mathrm{x}}} \mathrm{e}^{\frac{1}{2} \mathrm{~s}^{2}}-1\right) 100
$$

where $\mathrm{e}=$ the base of the natural logarithms.

The model was calibrated to node 27, the Yampa River below diversion, near Hayden (09244410), in a report by Parker and Norris (1983, table 4, p. 28). This node was recalibrated in this study, and the summary of errors is shown in table 4; graphical comparisons of calibrated model data and measured data for the variables for this node are shown in figures 5 through 7 .

Downstream from node 27 , there are three nodes used as output nodes and for calibration. These are (table 1): Node 39, Yampa River at Craig (09247500); node 51, Williams Fork at mouth, near Hamilton (09249750); and node 72, Yampa River near Maybel1 (09251000). Calibration at these nodes was done sequentially in a downstream direction.

Before calibration at node 39, Yampa River at Craig (09247500), the summation of streamflows, dissolved-solids concentrations, and dissolvedsolids loads from upstream were too small with respect to the measured values. 
Table 4.--Error analysis for modeled monthly mean streamflow, dissolvedsolids concentration, and dissolved-solids load for 72 months at node 27, Yampa River below diversion, near Hayden (09244410)

\begin{tabular}{lcclc}
\hline $\begin{array}{l}\text { Flow } \\
\text { regime }\end{array}$ & $\begin{array}{r}\text { Bias } \\
(\bar{x})\end{array}$ & $\begin{array}{c}\text { Variance } \\
\left(\mathbf{s}^{2}\right)\end{array}$ & $\begin{array}{l}\text { Mean square } \\
\text { error (MSE) }\end{array}$ & $\begin{array}{r}\text { Mean error } \\
\text { (percent) }\end{array}$ \\
\hline
\end{tabular}

Logarithm of monthly mean streamflow, in cubic feet per second

$\begin{array}{lrrrr}\text { Low flow } & -0.060 & 0.050 & 0.053 & -3.4 \\ \text { High flow } & 0.071 & 0.037 & 0.043 & 9.4 \\ \text { Combined flow } & -0.016 & 0.049 & 0.049 & 0.9\end{array}$

Logarithm of monthly mean dissolved-solids concentration, in milligrams per liter

$\begin{array}{lrrrr}\text { Low flow } & -0.101 & 0.020 & 0.030 & 11.8 \\ \text { High flow } & 0.015 & 0.056 & 0.056 & 4.4 \\ \text { Combined flow } & 0.072 & 0.033 & 0.038 & 9.3\end{array}$

Logarithm of monthly total dissolved-solids load, in tons per month

$\begin{array}{llllr}\text { Low flow } & 0.042 & 0.031 & 0.033 & 5.9 \\ \text { High flow } & 0.087 & 0.023 & 0.030 & 10.3 \\ \text { Combined flow } & 0.057 & 0.028 & 0.032 & 7.3\end{array}$

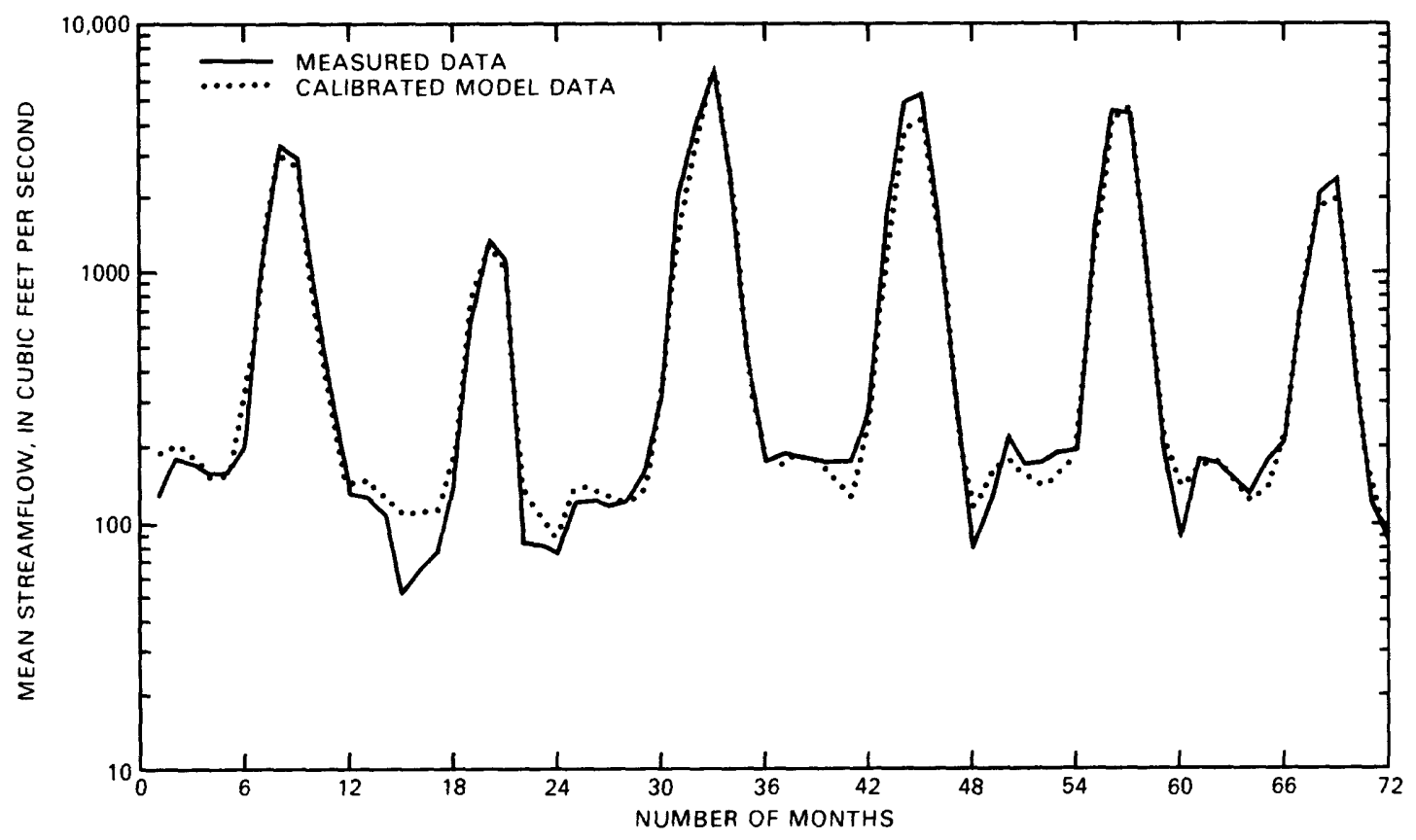

Figure 5.--A comparison of calibrated model data and measured streamflow at node 27, Yampa River below diversion, near Hayden (09244410). 


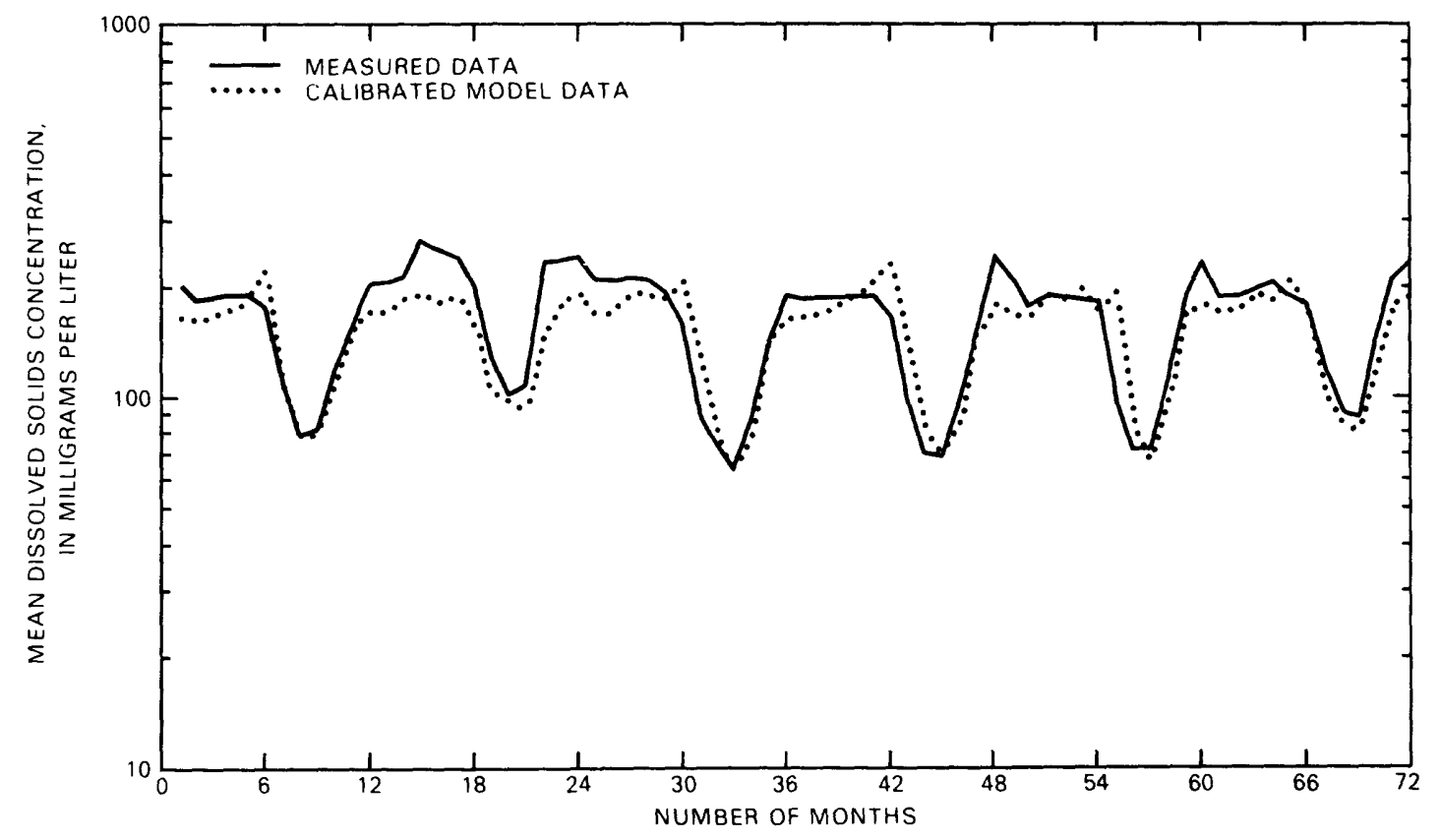

Figure 6.--A comparison of calibrated model data and measured dissolvedsolids concentration at node 27, Yampa River below diversion, near Hayden (09244410).

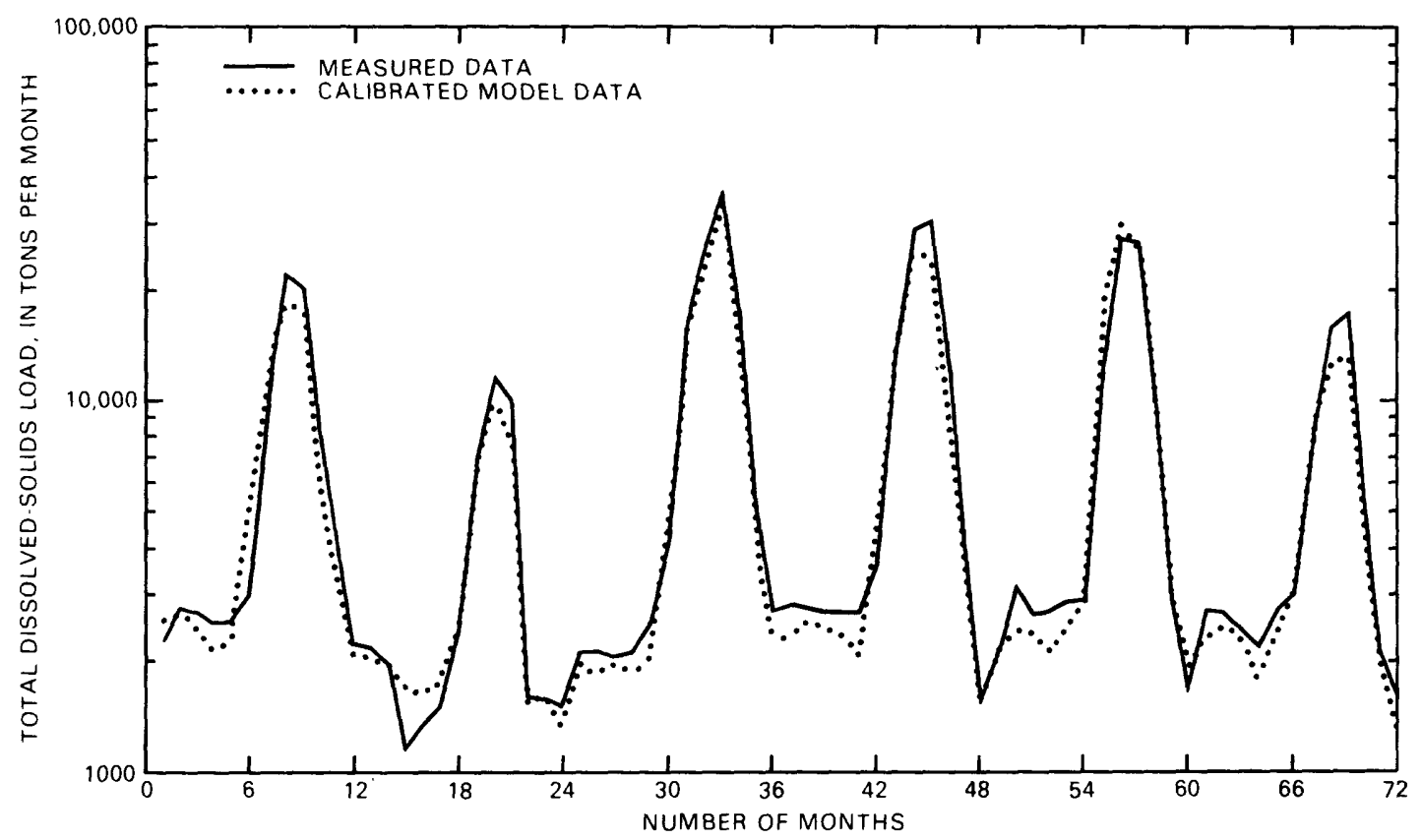

Figure 7.--A comparison of calibrated model data and measured total dissolved-solids load at node 27, Yampa River below diversion, near Hayden (09244410). 
These parameters were underpredicted for both low and high flows. The computed deficit at low flow probably does not account for base flows with large dissolved-solids concentration that enter from tributary and main-stem drainage areas downstream from input nodes. The high-flow deficit may result from unaccounted snowmelt runoff from the lower elevation tributary streams (for example, Dry, Elkhead, and Fortification Creeks). During the calibration process, it was necessary to adjust for the deficit at node 39. A graphical comparison of calibrated model data and measured data for streamflow, dissolved-solids concentration, and total monthly dissolved-solids load are shown in figures 8 through 10 . Error statistics for the calibrated node are shown in table 5 .

Node 51, Williams Fork at mouth, near Hamilton (09249750), is the next output node. Before calibration, the summation of data from upstream showed that streamflow errors were small during high flows and larger during low flows; dissolved-solids concentrations and loads were underpredicted for all flows. This indicates no significant snowmelt discharge, but a significant dissolved-solids base-flow component contributed by the lower Williams Fork basin was needed. Error statistics for the calibi--od node are shown in table 6. Graphical comparison of calibrated model data and measured data for this node are shown in figures 11 through 13.

The final output node 72, Yampa River near Maybell (0925100 _, was the last node to be calibrated. Graphical comparison of calibrated model data and measured data for this node are shown in figures 14 through 16 . The error statistics are shown in table 7 .

It was necessary in calibration to add a small amount of water in the upstream reach having a large concentration of dissolved solids. The need to increase dissolved-solids concentration during calibration at this final output node may represent ground-water inflow in the reach from Craig to Maybel1. Warner and Dale (1981) indicate a ground-water inflow of 5 to 8 cubic feet per second into the Yampa River in the reach from Hayden to the confluence with the Williams Fork. These values are similar in magnitude to the inflow used for calibration of this model for the reach from the confluence of Williams Fork to Maybell. The assumed reach concentration for dissolved solids is at the upper limit of concentrations found in ground water in this area (Brogden and Giles, 1977).

\section{FUTURE DATA-COLLECTION NEEDS}

From the extrapolations in data that were needed and the assumptions necessary in calibration, several important considerations for future data collection are indicated. Very little data are available near the outlets of several tributaries. Within the model, streamflow and associated dissolved solids were routed along these tributaries directly from upstream nodes with no changes in the intervening reach. Additional information about streamflow and dissolved solids near the outlets of these tributaries would improve the model. These tributary streams include: Dry Creek, Sage Creek, Elkhead Creek, Fortification Creek, and Milk Creek. 


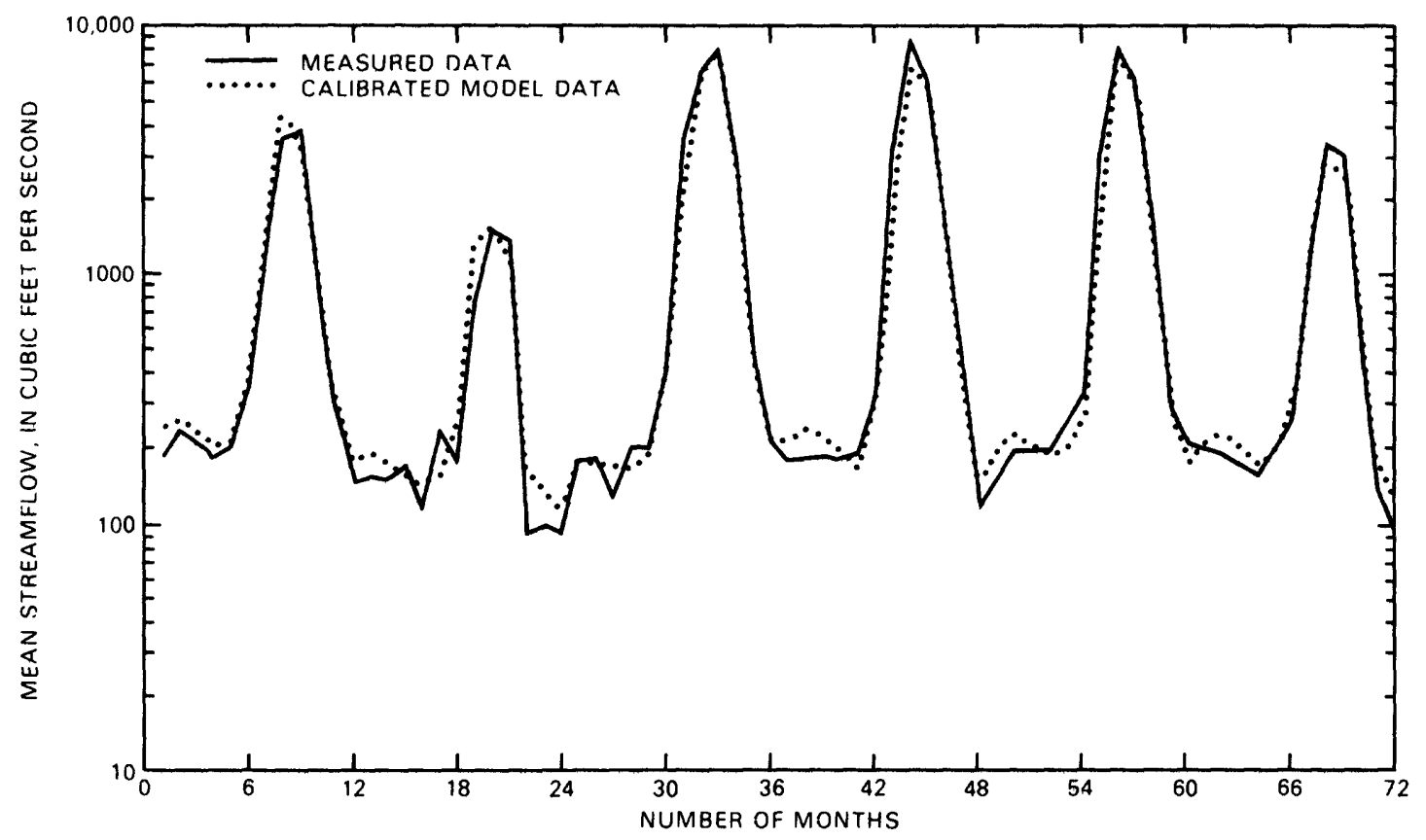

Figure 8.--A comparison of calibrated model data and measured streamflow at node 39, Yampa River at Craig (09247500).

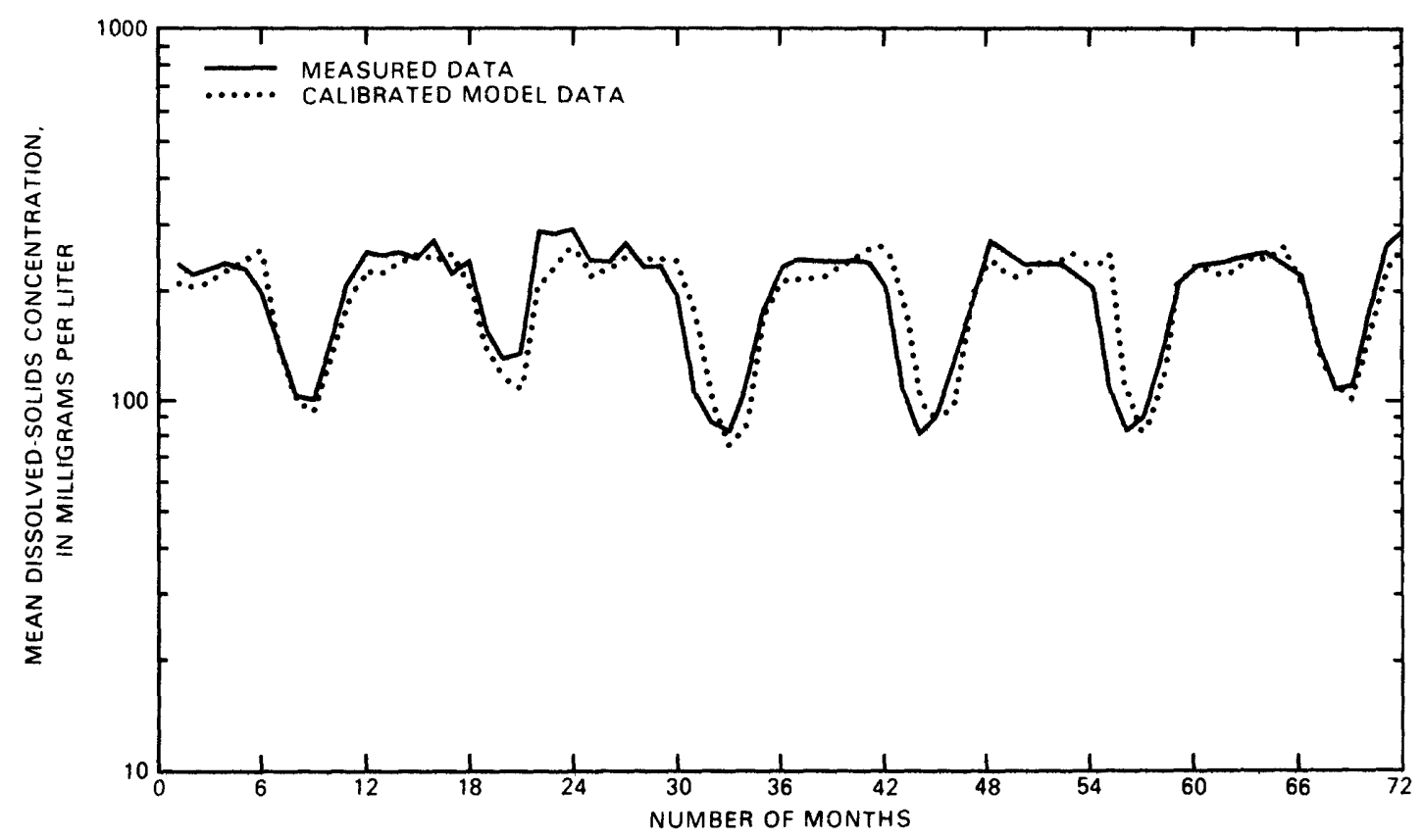

Figure 9.--A comparison of calibrated model data and measured dissolvedsolids concentration at node 39, Yampa River at Craig (09247500). 


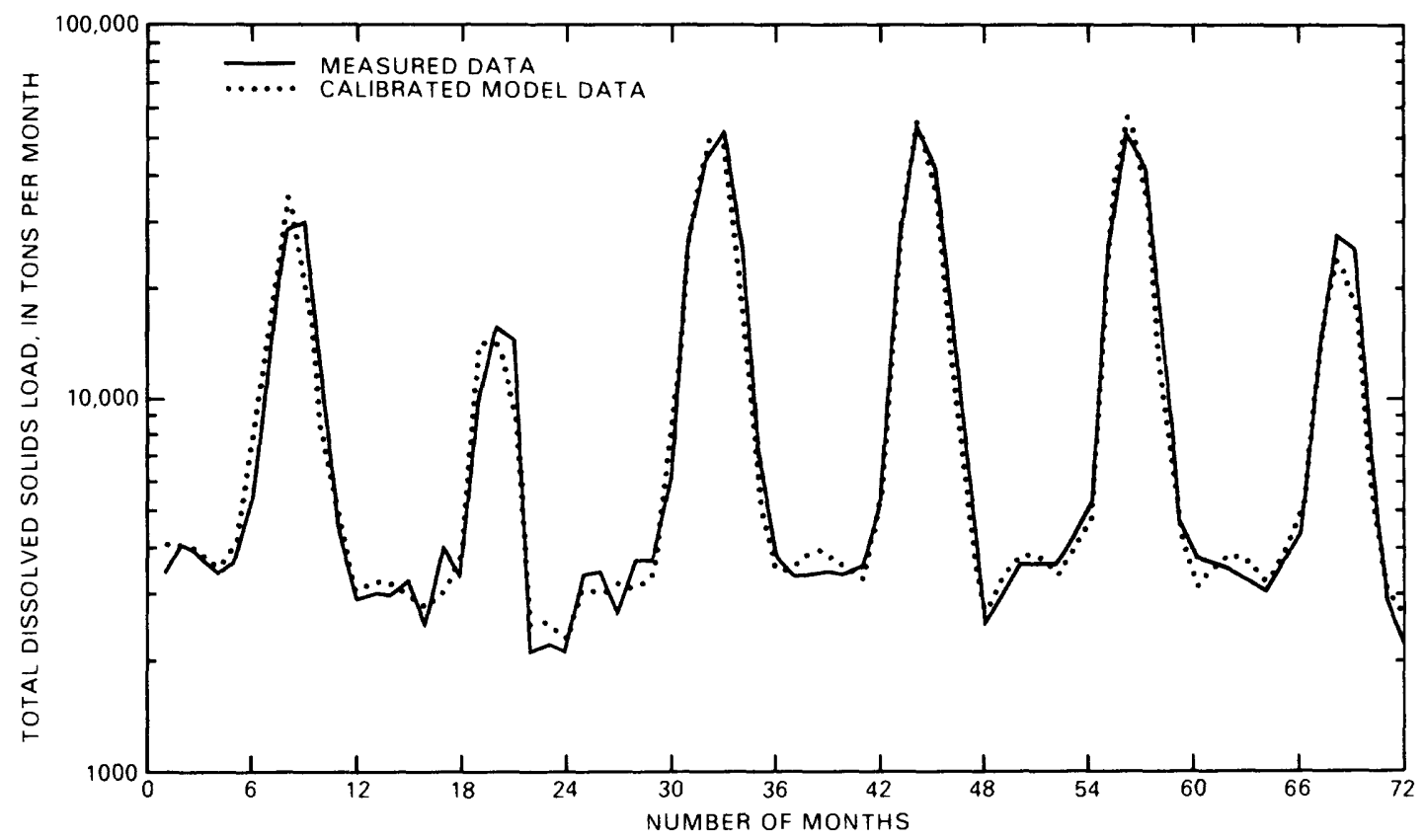

Figure 10.--A comparison of calibrated model data and measured total dissolved-solids load at node 39, Yampa River at Craig (09247500).

The streamflow-gaging station, Milk Creek near Thornburgh (09250000), represents a long-term record in the southwestern part of the study area. Unfortunately, little additional data exist for streams in this area. Waddle Creek, Morapos Creek, and Deer Creek are near Milk Creek, but available data are from sites with periodic measurements only. Willow Creek, which flows into the East Fork Williams Fork, is another drainage system with only a site with periodic measurements. Further data collection is warranted.

At input nodes where only a few streamflow measurements are available, a ratio was developed using a long-term streamflow-gaging station in the area. Ratios were determined for each instantaneous streamflow measurement at the input node and the concurrent mean daily value at the streamflow-gaging station. The mean value of these ratios then was used to estimate monthly mean streamflow based on monthly mean streamflow at the station. The values of the individual ratios generally vary inversely with streamflow. Therefore, the use of the mean ratio tends to overestimate the high flow and to underestimate the low flow.

Data extrapolated for this report may be useful for many applications. However, determining specific, cumulative effects in the basins mentioned above would require additional data within those basins. Some streams are smal1, and additional data collection may be unwarranted. Future mining interest could provide an impetus for data collection at some later time. An example of such a tributary is Lay Creek, where little information is available now. The usefulness of the information regarding the overall water 
Table 5.--Error analysis for modeled monthly mean streamflow, dissolvedsolids concentration, and dissolved-solids load for 72 months at node 39, Yampa River at Craig (09247500)

\begin{tabular}{lcclc}
\hline $\begin{array}{l}\text { Flow } \\
\text { regime }\end{array}$ & $\begin{array}{r}\text { Bias } \\
(\bar{x})\end{array}$ & $\begin{array}{c}\text { Variance } \\
\left(\mathbf{s}^{2}\right)\end{array}$ & $\begin{array}{l}\text { Mean square } \\
\text { error (MSE) }\end{array}$ & $\begin{array}{r}\text { Mean error } \\
\text { (percent) }\end{array}$ \\
\hline
\end{tabular}

Logarithm of monthly mean streamflow, in cubic feet per second

$\begin{array}{lrrrr}\text { Low flow } & -0.061 & 0.030 & 0.034 & -4.5 \\ \text { High flow } & 0.093 & 0.081 & 0.090 & 14.3 \\ \text { Combined flow } & -0.009 & 0.051 & 0.052 & 1.6\end{array}$

Logarithm of monthly mean dissolved-solids concentration, in milligrams per liter

$\begin{array}{lrrrr}\text { Low flow } & 0.032 & 0.011 & 0.012 & 3.8 \\ \text { High flow } & -0.006 & 0.081 & 0.081 & 3.5 \\ \text { Combined flow } & 0.019 & 0.034 & 0.034 & 3.7\end{array}$

Logarithm of total monthly dissolved-solids load, in tons per month

$\begin{array}{lrrrr}\text { Low flow } & -0.028 & 0.020 & 0.021 & -1.8 \\ \text { High flow } & 0.087 & 0.052 & 0.060 & 12.0 \\ \text { Combined flow } & 0.010 & 0.033 & 0.033 & 2.7\end{array}$

Table 6.--Error analysis for modeled monthly mean streamflow, dissolvedsolids concentration, and dissolved-solids load for 72 months at node 51, Williams Fork at mouth, near Hamilton (09249750)

\begin{tabular}{|c|c|c|c|c|c|}
\hline $\begin{array}{l}\text { Flow } \\
\text { regime }\end{array}$ & $\begin{array}{l}\text { Bias } \\
(\bar{x})\end{array}$ & $\begin{array}{l}\text { Variance } \\
\qquad\left(\mathbf{s}^{2}\right)\end{array}$ & $\begin{array}{l}\text { Mean square } \\
\text { error (MSE) }\end{array}$ & & $\begin{array}{l}\text { Mean er } \\
\text { (percel }\end{array}$ \\
\hline \multicolumn{2}{|c|}{ Logarithm of monthly } & $y$ mean str & $w$, in cubic & feet per & secon \\
\hline Low flow & 0.032 & 0.129 & 0.130 & & 10.1 \\
\hline High flow & -0.073 & 0.062 & 0.067 & & -4.1 \\
\hline Combined flow & -0.003 & 0.108 & 0.108 & & 5.2 \\
\hline
\end{tabular}

Logarithm of monthly mean dissolved-solids concentration,

\begin{tabular}{lrccc} 
& & in milligrams & per liter & \\
\cline { 3 - 4 } Low flow & -0.089 & 0.015 & 0.023 & -7.8 \\
High flow & 0.127 & 0.021 & 0.037 & 14.7 \\
Combined flow & -0.017 & 0.027 & 0.027 & -0.3
\end{tabular}

L'ogarithm of total monthly dissolved-solids load, in tons per month

$\begin{array}{lrrrr}\text { Low flow } & -0.057 & 0.078 & 0.082 & -1.8 \\ \text { High flow } & 0.054 & 0.025 & 0.028 & 6.9 \\ \text { Combined flow } & -0.020 & 0.063 & 0.063 & 1.2\end{array}$




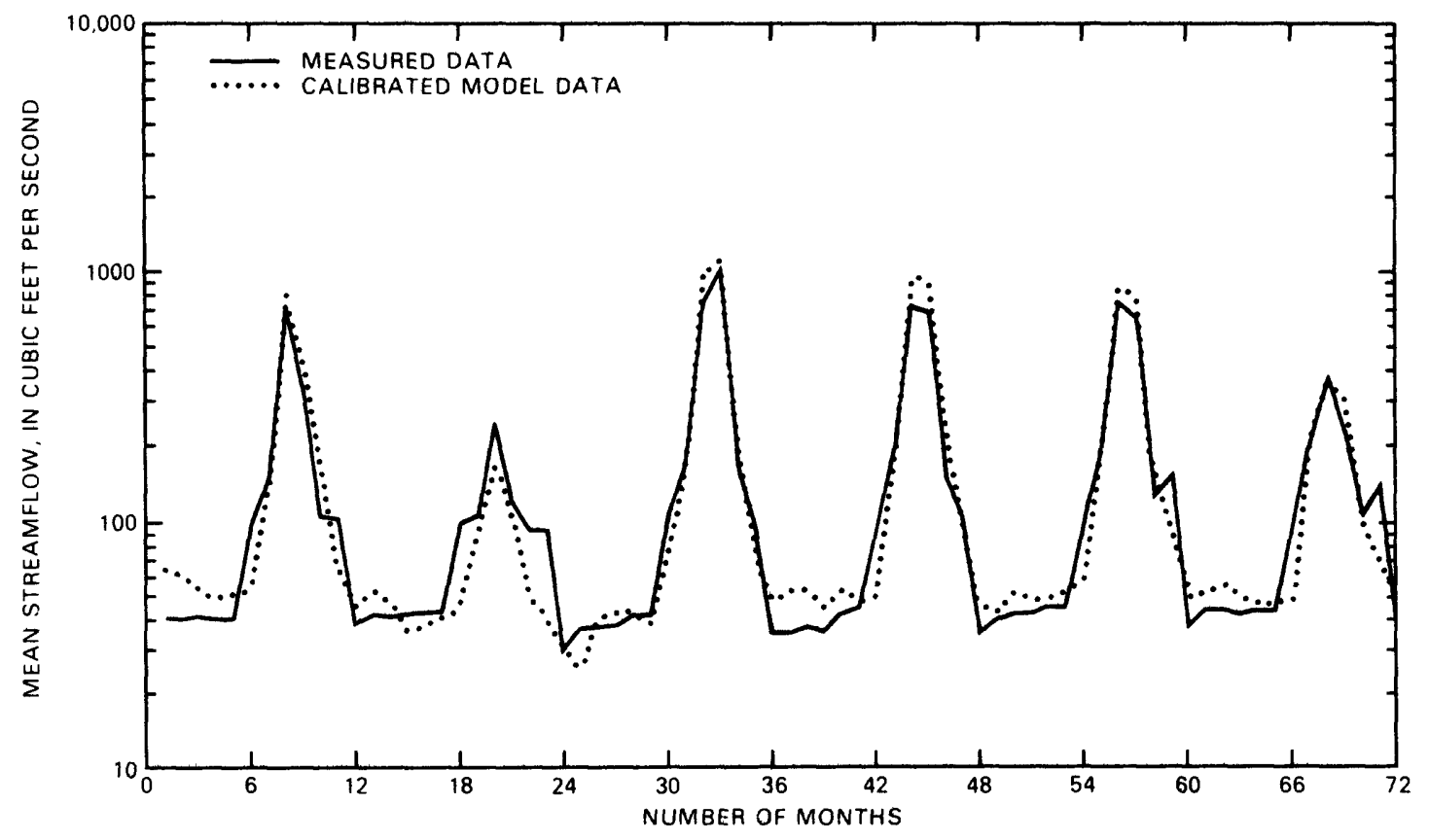

Figure 11.--A comparison of calibrated model data and measured streamflow at node 51, Williams Fork at mouth, near Hamilton (09249750).

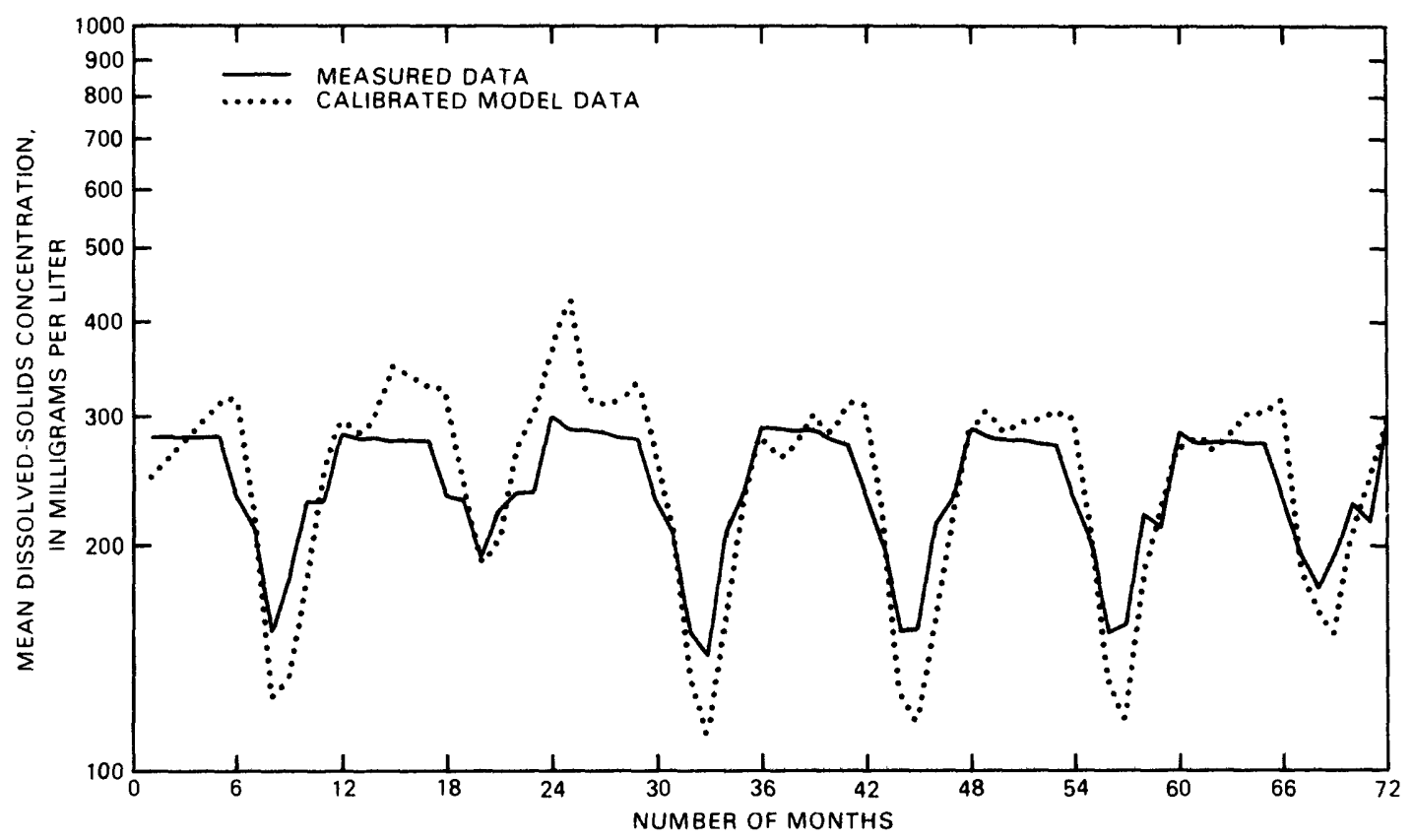

Figure 12.--A comparison of calibrated model data and measured dissolvedsolids concentration at node 51 , Williams Fork at mouth, near Hamilton (09249750). 


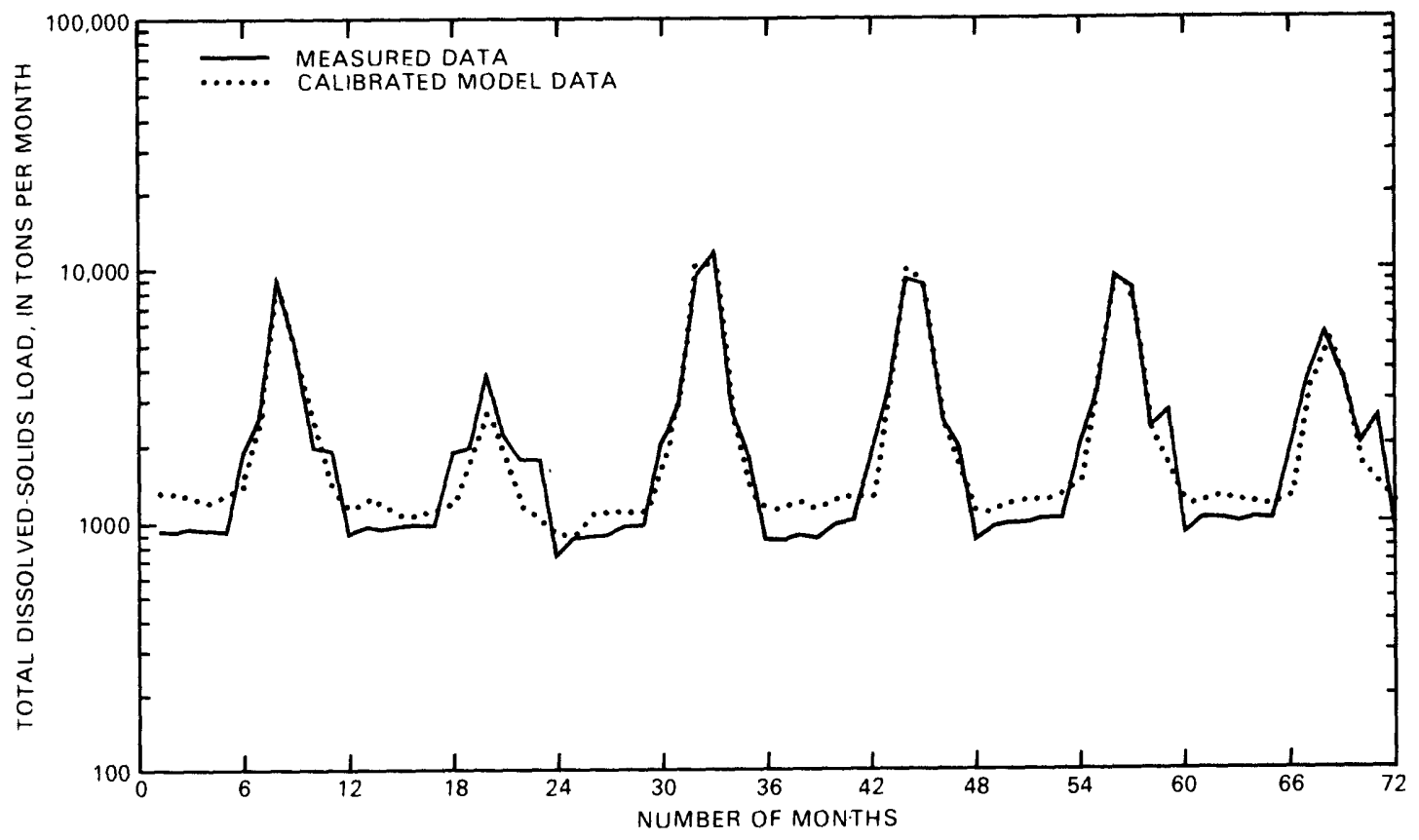

Figure 13.--A comparison of calibrated model data and measured total dissolved-solids load at node 51, Williams Fork at mouth, near Hamilton (09249750).

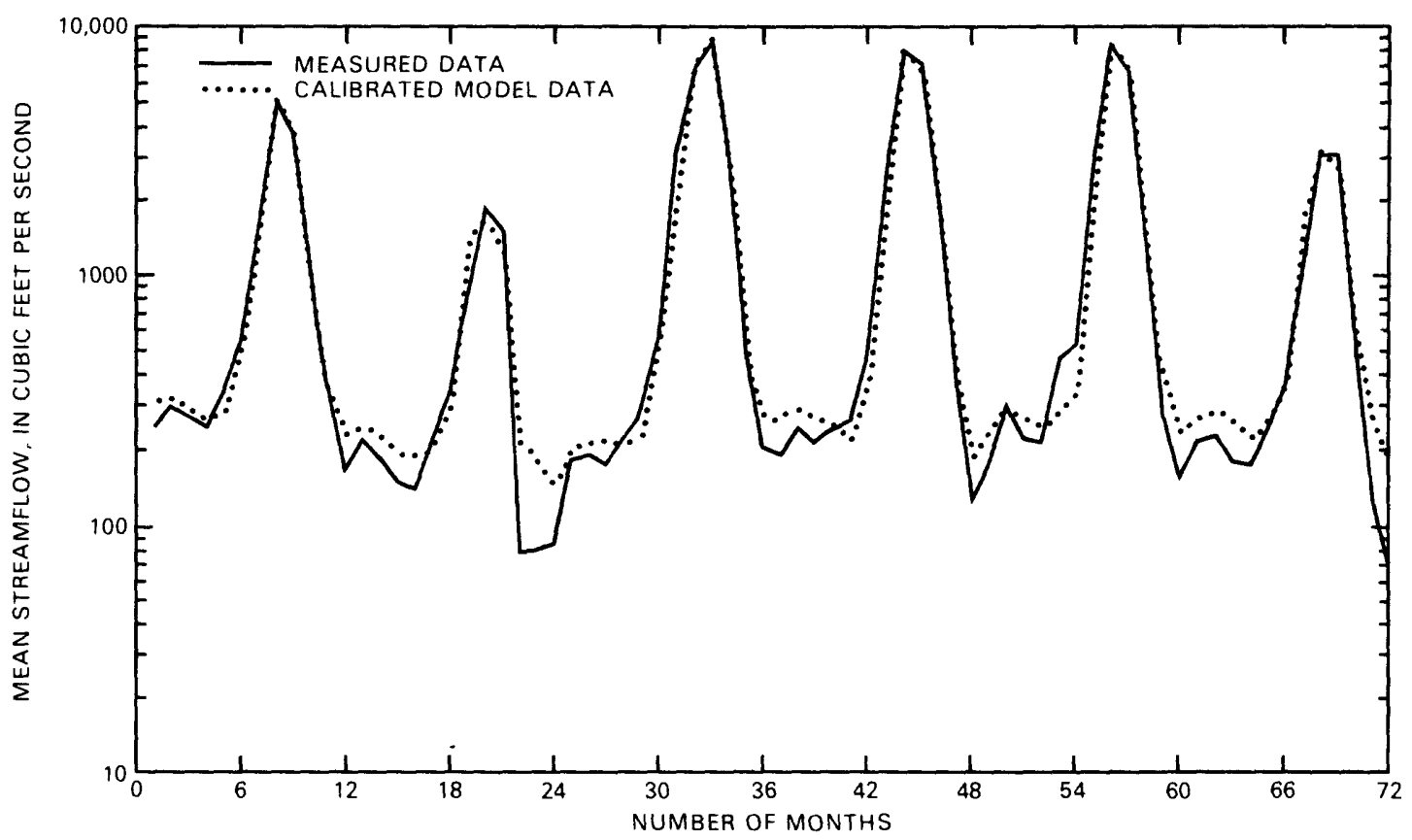

Figure 14.--A comparison of calibrated model data and measured streamflow at node 72, Yampa River near Maybell (09251000). 


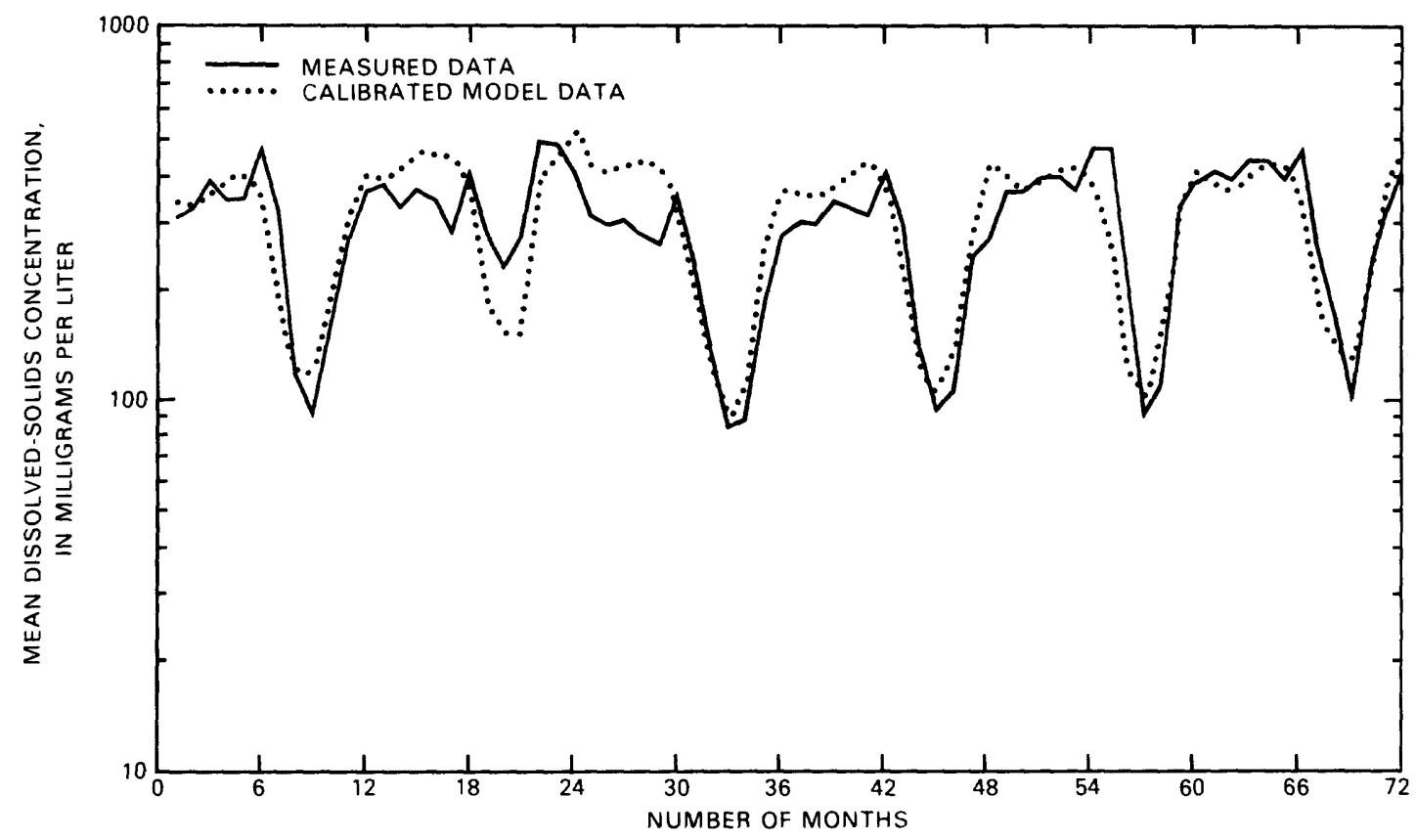

Figure 15.--A comparison of calibrated model data and measured dissolvedsolids concentration at node 72, Yampa River near Maybe11 (09251000).

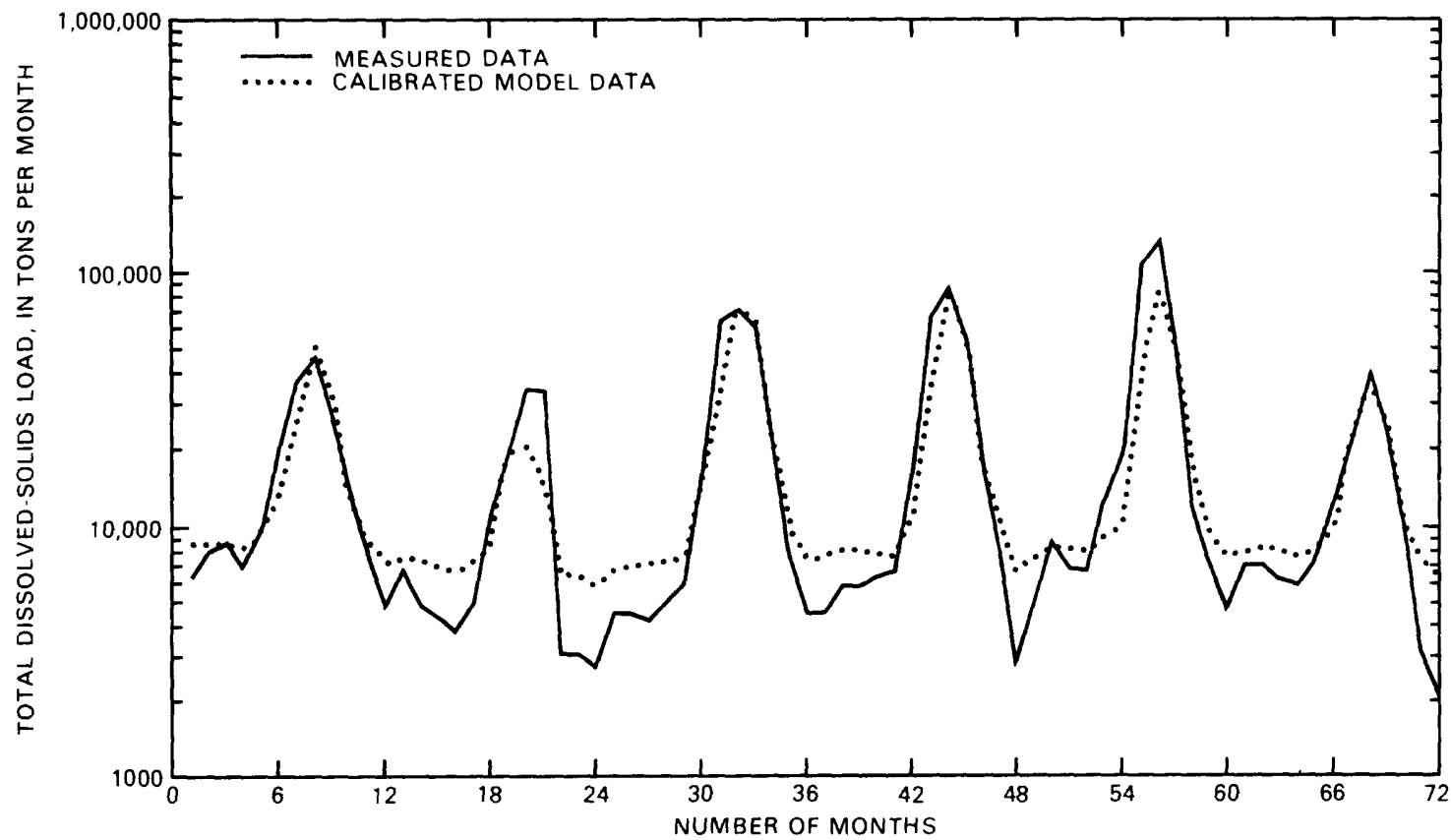

Figure 16.--A comparison of calibrated model data and measured total dissolved-solids load at node 72, Yampa River near Maybe11 (09251000). 
balance in the model is minimal. The extrapolated data used in this report probably are sufficient at this time. Increased mining interest in the watershed could indicate a need for more in-depth analysis of this basin and for more data collection.

\section{SUMMARY AND CONCLUSIONS}

The stream system of the Yampa River and its tributaries between Steamboat Springs and Maybell was represented by an accounting model with 72 nodes. The model computes monthly mean streamflow, dissolved-solids concentration, and dissolved-solids load at the internal and output nodes. It requires monthly mean streamflow and dissolved-solids concentrations at input nodes .

Although specific effects of mining were not simulated, a framework was developed that may be modified for simulation of effects on the entire system or any part of it. Streamflow statistics, including monthly and annual means, can be predicted at each internal and output node.

All available U.S. Geological Survey surface-water quantity and quality data that were collected in the study area prior to 1982 were examined during development of the necessary data base. Although the data base is adequate to define the general surface-water system, it has many deficiencies. One benefit of using a model such as the one used in this study is the opportunity to identify streams that need further data collection.

A number of tributaries have few data near their mouths. Within the model, streamflow and associated dissolved solids were routed directly from upstream nodes with no changes in the intervening reach. Additional information about streamflow and dissolved solids near the outlets of these tributaries would improve the model.

The streamflow-gaging station, Milk Creek near Thornburgh (09250000), represents a long-term record in the southwestern part of the study area. Unfortunately, few data exist for streams in this area, and necessary streamflow data were computed using instantaneous measurements at periodic data-collection sites and using the long-term streamflow record at gaging stations. Such techniques may be satisfactory for an overall analysis of the Yampa River basin but may be severely limiting in identifying effects within the small tributaries themselves.

Calibration was done at four nodes, $27,39,51$, and 72 . Specific calibration within tributaries would be necessary to model subdrainages in more detail. Modeled parameters had errors for combined flow of less than 4 percent at Yampa River at Craig; less than 6 percent for the Williams Fork at mouth, near Hamilton; and less than 4 percent at the final output node, Yampa River near Maybell.

The model is useful for determining cumulative effects of dissolvedsolids concentration and loads without introducing complex relations that require extensive data collection. The model is not complex; water needs to be added and modified through the use of only two simple equations, a linear reach equation and a logarithmic relation between streamflow and dissolved solids. However, more complex relations could be added. 
Table 7.--Error analysis for modeled monthly mean streamflow, dissolvedsolids concentration, and dissolved-solids load for 72 months at node 72, Yampa River near Maybel1 (09251000)

\begin{tabular}{|c|c|c|c|c|}
\hline $\begin{array}{l}\text { Flow } \\
\text { regime }\end{array}$ & $\begin{array}{c}\text { Bias } \\
(\bar{x})\end{array}$ & $\begin{array}{l}\text { Variance } \\
\quad\left(s^{2}\right)\end{array}$ & $\begin{array}{l}\text { Mean square } \\
\text { error (MSE) }\end{array}$ & $\begin{array}{r}\text { Mean error } \\
\text { (percent) }\end{array}$ \\
\hline \multicolumn{5}{|c|}{ Logarithm of monthly mean streamflow in cubic feet per second } \\
\hline $\begin{array}{l}\text { Low flow } \\
\text { High flow } \\
\text { Combined flow }\end{array}$ & $\begin{array}{r}-0.127 \\
0.003 \\
-0.084\end{array}$ & $\begin{array}{l}0.082 \\
0.089 \\
0.087\end{array}$ & $\begin{array}{l}0.098 \\
0.089 \\
0.094\end{array}$ & $\begin{array}{r}-8.2 \\
4.9 \\
-3.9\end{array}$ \\
\hline \multicolumn{5}{|c|}{$\frac{\text { Logarithm of monthly mean dissolved-solids concentration, }}{\text { in milligrams per liter }}$} \\
\hline $\begin{array}{l}\text { Low flow } \\
\text { High flow } \\
\text { Combined flow }\end{array}$ & $\begin{array}{r}-0.109 \\
0.107 \\
-0.037\end{array}$ & $\begin{array}{l}0.036 \\
0.091 \\
0.064\end{array}$ & $\begin{array}{l}0.048 \\
0.102 \\
0.065\end{array}$ & $\begin{array}{l}-8.7 \\
16.4 \\
-0.6\end{array}$ \\
\hline \multicolumn{5}{|c|}{ Logarithm of total monthly dissolved-solids load, in tons per month } \\
\hline $\begin{array}{l}\text { Low flow } \\
\text { High flow } \\
\text { Combined flow }\end{array}$ & $\begin{array}{r}-0.236 \\
0.110 \\
-0.121\end{array}$ & $\begin{array}{l}0.123 \\
0.160 \\
0.160\end{array}$ & $\begin{array}{l}0.178 \\
0.172 \\
0.175\end{array}$ & $\begin{array}{r}-16.1 \\
20.9 \\
-4.0\end{array}$ \\
\hline
\end{tabular}

\section{REFERENCES}

Brogden, R.E., and Giles, T.F., 1977, Reconnaissance of ground-water resources in a part of the Yampa River basin between Craig and Steamboat Springs, Moffat and Routt Counties, Colorado: U.S. Geological Survey Water-Resources Investigations 77-4, 1 sheet, scale $1: 250,000$.

Hem, J.D., 1970, Study and interpretation of the chemical characteristics of natural water: U.S. Geological Survey Water-Supply Paper 1473, 363 p.

Matalas, N.C., 1967, Mathematical assessment of synthetic hydrology: Water Resources Research, v. 3, no. 4, p. 937-946.

Maura, W.S., 1982, Water-quality data for streams in the southern Yampa River basin, northwestern Colorado: U.S. Geological Survey Open-File Report $82-1017,112 \mathrm{p}$. 1985, Selected trace-element data for streams in the southern Yampa River basin, northwestern Colorado: U.S. Geological Survey Open-File Report 85-192, $154 \mathrm{p}$.

Parker, R.S., and Norris, J.M., 1983, Simulated effects of anticipated coal mining on dissolved solids in selected tributaries of the Yampa River, northwestern Colorado: U.S. Geological Survey Water-Resources Investigations 83-4084, $66 \mathrm{p}$.

Ribbens, R.W., 1975, Program NW01, river network program, Users Manual: Denver, U.S. Bureau of Reclamation, Engineering Research Center, Division of Planning and Coodination, 7 chapters.

Warner, J.W., and Dale, R.H., 1981, Digital-transport model of the potential effects of coal-resource development on the ground-water system in the Yampa River Basin, Moffat and Routt Counties, Colorado: U.S. Geological Survey Water-Resources Investigations $81-15,70 \mathrm{p}$.

Woods, P.F., 1981, Modeled impacts of surface coal mining on dissolved solids on the Tongue River, southeastern Montana, U.S. Geological Survey WaterResources Investigations 81-64, $73 \mathrm{p}$. 
SUPPLEMENTAL DATA 
Table 8.--Linear-regression equations for predicting monthly mean streamflow North Fork Elkhead Creek near Elkhead (09245500)

$\left[Q_{p}\right.$, predicted monthly mean streamflow, in cubic feet per second, North Fork Elkhead Creek near Elkhead (09245500); $Q_{0}$, concurrent monthly mean streamflow, in cubic feet per second, for the streamflow-gaging station, Elkhead Creek near Elkhead (09245000)]

\begin{tabular}{|c|c|c|c|c|c|}
\hline Month & & Equation & $\begin{array}{l}\text { Number } \\
\text { of data } \\
\text { pairs }\end{array}$ & $\begin{array}{l}\text { Standard } \\
\text { error } \\
\text { (cubic } \\
\text { feet per } \\
\text { second) }\end{array}$ & $\begin{array}{l}\text { Coefficient } \\
\text { of } \\
\text { determination }\end{array}$ \\
\hline October & $Q_{p}$ & $=0.40+0.23 Q_{0}$ & 15 & 0.59 & $0.75 *$ \\
\hline November & $Q_{p}$ & $=0.93+0.15 Q_{0}$ & 15 & 0.52 & $0.62 *$ \\
\hline December & $Q_{p}$ & $=0.96+0.15 Q_{0}$ & 15 & 0.46 & $0.61 *$ \\
\hline January & $Q_{p}$ & $=0.91+0.18 Q_{0}$ & 15 & 0.43 & $0.68 \%$ \\
\hline February & $Q_{p}$ & $=0.97+0.19 Q_{0}$ & 15 & 0.47 & $0.61 *$ \\
\hline March & $Q_{p}$ & $=0.77+0.38 Q_{0}$ & 15 & 1.28 & $0.91 *$ \\
\hline April & $Q_{p}$ & $=4.51+0.33 Q_{0}$ & 15 & 9.30 & $0.96 *$ \\
\hline May & $Q_{p}$ & $=27.6+0.40 Q_{0}$ & 15 & 17.0 & $0.94 *$ \\
\hline June & $Q_{p}$ & $=0.32+0 . Q_{0}$ & 15 & 4.57 & $0.98 *$ \\
\hline July & $Q_{p}$ & $=0.52+0.24 Q_{0}$ & 15 & 0.71 & $0.94 \%$ \\
\hline August & $Q_{p}$ & $=0.98+0.17 Q_{0}$ & 15 & 0.28 & $0.84 *$ \\
\hline September & $Q_{p}$ & $=0.18+0.28 Q_{0}$ & 15 & 0.42 & $0.80 \%$ \\
\hline
\end{tabular}

*Significant at the 95-percent level. 
Table 9.--Linear-regression equations for predicting monthly mean streamflow for node 37, Fortification Creek near Craig (09246900)

$\left[Q_{p}\right.$, predicted monthly mean streamflow, in cubic feet per second, for node 37 , Fortification Creek near Craig (09246900); $Q_{0}$, concurrent monthly mean streamflow, in cubic feet per second, for the streamflow-gaging station, E1khead Creek near E1khead (09245000)]

\begin{tabular}{|c|c|c|c|c|c|}
\hline Month & & Equation & $\begin{array}{l}\text { Number } \\
\text { of data } \\
\text { pairs }\end{array}$ & $\begin{array}{l}\text { Standard } \\
\text { error } \\
\text { (cubic } \\
\text { feet per } \\
\text { second) }\end{array}$ & $\begin{array}{l}\text { Coefficient } \\
\text { of } \\
\text { determination }\end{array}$ \\
\hline October & $Q_{p}$ & $=-0.91+0.68 Q_{0}$ & 5 & 0.791 & $0.83 *$ \\
\hline November & $Q_{p}$ & $=0.80+0.32 Q_{0}$ & 5 & 0.808 & 0.54 \\
\hline December & $Q_{p}$ & $=1.21+0.15 Q_{0}$ & 5 & 0.325 & 0.62 \\
\hline January & $Q_{p}$ & $=1.45+0.11 Q_{0}$ & 5 & 0.266 & 0.49 \\
\hline February & $Q_{p}$ & $=1.07+0.20 Q_{0}$ & 5 & 0.420 & $0.79 *$ \\
\hline March & $Q_{p}$ & $=1.46+1.03 Q_{0}$ & 5 & 7.44 & 0.35 \\
\hline April & $Q_{p}$ & $=21.60+0.06 Q_{0}$ & 5 & 8.54 & $0.33 *$ \\
\hline May & $Q_{p}$ & $=-29.34+0.23 Q_{0}$ & 5 & 11.83 & $0.87 *$ \\
\hline June & $Q_{p}$ & $=2.11+0.23 Q_{0}$ & 5 & 5.48 & $0.98 *$ \\
\hline July & $Q_{p}$ & $=-2.00+0.41 Q_{0}$ & 5 & 0.22 & $0.99 *$ \\
\hline August & $Q_{p}$ & $=-0.17+0.17 Q_{0}$ & 5 & 0.13 & $0.98 *$ \\
\hline September & $Q_{p}$ & $=-0.01+0.21 Q_{0}$ & 5 & 0.38 & $0.59 *$ \\
\hline
\end{tabular}

$*$ Significant at the 95 -percent level. 
Table 10.--Linear-regression equations for predicting monthly mean streamflow for node 40, East Fork of Williams Fork, above Willow Creek (09248600)

$\left[Q_{p}\right.$, predicted monthly mean streamflow, in cubic feet per second, for node 40 , East Fork of Williams Fork, above Willow Creek (09248600); $Q_{0}$, concurrent monthly mean streamflow, in cubic feet per second, for the streamflow-gaging station, White River above Coal Creek near Meeker (09304200)]

\begin{tabular}{|c|c|c|c|c|c|}
\hline Month & & Equation & $\begin{array}{l}\text { Number } \\
\text { of data } \\
\text { pairs }\end{array}$ & $\begin{array}{c}\text { Standard } \\
\text { error } \\
\text { (cubic } \\
\text { feet per } \\
\text { second) }\end{array}$ & $\begin{array}{l}\text { Coefficient } \\
\text { of } \\
\text { determination }\end{array}$ \\
\hline October & $Q_{p}$ & $=-17.73+0.16 Q_{0}$ & 11 & 10.65 & $0.67 \%$ \\
\hline November & $Q_{p}$ & $=-9.75+0.13 Q_{0}$ & 11 & 4.54 & $0.69 *$ \\
\hline December & $Q_{p}$ & $=-10.38+0.13 Q_{0}$ & 11 & 2.82 & $0.79 *$ \\
\hline January & $Q_{p}$ & $=-3.00+0.10 Q_{0}$ & 11 & 3.06 & $0.48 \%$ \\
\hline February & $Q_{p}$ & $=-8.28+0.12 Q_{0}$ & 11 & 3.98 & $0.42 *$ \\
\hline March & $Q_{p}$ & $=-9.75+0.13 Q_{0}$ & 11 & 4.58 & $0.52 \%$ \\
\hline April & $Q_{p}$ & $=-62.96+0.31 Q_{0}$ & 11 & 12.05 & $0.97 *$ \\
\hline May & $Q_{p}$ & $=-44.03+0.28 Q_{0}$ & 11 & 28.36 & $0.93 *$ \\
\hline June & $Q_{p}$ & $=31.97+0.20 Q_{0}$ & 11 & 20.17 & $0.98 *$ \\
\hline July & $Q_{p}$ & $=26.15+0.18 Q_{0}$ & 11 & 16.80 & $0.90 *$ \\
\hline August & $Q_{p}$ & $=12.05+0.11 Q_{0}$ & 11 & 9.96 & $0.71 *$ \\
\hline September & $Q_{p}$ & $=5.04+0.11 Q_{0}$ & 11 & 2.87 & $0.93 *$ \\
\hline
\end{tabular}

*Significant at the 95-percent level. 
Table 11.--Linear regression equations for predicting monthly mean streamflow for node 44, South Fork of Williams Fork, near Pagoda (09249200)

$\left[Q_{p}\right.$, predicted monthly mean streamflow, in cubic feet per second, for node 44, South Fork of Williams Fork, near Pagoda (09249200); $Q_{0}$, concurrent monthly mean streamflow, in cubic feet per second, for the streamflow-gaging station, White River above Coal Creek near Meeker (09304200)]

\begin{tabular}{|c|c|c|c|c|c|}
\hline Month & & Equation & $\begin{array}{l}\text { Number } \\
\text { of data } \\
\text { pairs }\end{array}$ & $\begin{array}{l}\text { Standard } \\
\text { error } \\
\text { (cubic } \\
\text { feet per } \\
\text { second) }\end{array}$ & $\begin{array}{l}\text { Coefficient } \\
\text { of } \\
\text { determination }\end{array}$ \\
\hline October & $Q_{p}$ & $=-3.06+-.03 Q_{0}$ & 14 & 2.36 & $0.51 *$ \\
\hline November & $\mathrm{Q}_{\mathrm{p}}$ & $=-2.29+0.02 Q_{0}$ & 14 & 1.61 & $0.43 *$ \\
\hline December & $Q_{p}$ & $=1.16+0.14 Q_{0}$ & 14 & 1.07 & $0.29 \%$ \\
\hline January & $Q_{p}$ & $=3.78+0.007 Q_{0}$ & 14 & 0.93 & 0.08 \\
\hline February & $Q_{p}$ & $=1.42+0.016 Q_{0}$ & 14 & 0.80 & $0.32 *$ \\
\hline March & $Q_{p}$ & $=-3.48+0.04 Q_{0}$ & 14 & 2.03 & $0.42 \%$ \\
\hline April & $Q_{p}$ & $=-64.91+0.23 Q_{0}$ & 14 & 9.87 & $0.90 *$ \\
\hline May & $Q_{p}$ & $=3.92+0.15 Q_{0}$ & 14 & 26.99 & $0.90 \%$ \\
\hline June & $Q_{p}$ & $=-38.47+.0 .12 Q_{0}$ & 14 & 28.48 & $0.92 *$ \\
\hline July & $Q_{p}$ & $=-0.67+0.04 Q_{0}$ & 14 & 2.55 & $0.95 *$ \\
\hline August & $Q_{p}$ & $=1.58+0.12 Q_{0}$ & 14 & 1.36 & $0.44 \%$ \\
\hline September & $Q_{p}$ & $=-0.56+0.0017_{0}$ & 14 & 1.03 & $0.70 *$ \\
\hline
\end{tabular}

*Significant at the 95-percent level. 